\title{
MENINGKATKAN PENGUASAAN VOCABULARIES SISWA MELALUI LAGU - LAGU BAHASA INGGRIS DI KELAS VIII-2 SMP NEGERI 2 MARDINGDING SEMESTER GANJIL TAHUN PELAJARAN 2015/2016
}

\author{
Jendakita Br Sinulingga \\ Email: jendakita1972@gmail.com.
}

\begin{abstract}
This study aims to improve student learning outcomes in learning English by using the media of English songs. The subjects of this study were 27 students of class VIII-2 of SMP Negeri 2 Mardingding, Mardingding District, Karo Regency, consisting of 11 male students and 16 female students. The research method applied is a classroom action research method. Through two learning cycles, each cycle is carried out with planning, implementation, observation and reflection activities. Based on the results of data analysis, it is known that by using the media of English songs in English lessons in class VIII-2 of SMP Negeri 2 Mardingding, Mardingding District, Karo Regency, 2015/2016 Academic Year, mastery of students' vocabularies has increased from Cycle First to Cycle Second. Mastery of students' vocabularies in the first cycle obtained an average score of 30 with the percentage of the acquisition score of the total score of $30 \%$ and this is in the very poor category (not good). And far from $\mathrm{kkm}$ (70). In the second cycle of vocabulary mastery students obtained an average score of 80 with a percentage of the acquisition score of a total score of $80 \%$ and this is in the good category, and has exceeded $\mathrm{kkm}(70)$. So, the increase in students' vocabularies mastery from cycle I to cycle II was 50\%, while student learning outcomes after using English songs as media in learning English also increased. Likewise, the number of students who have completed the KKM has reached the indicators of success, where the standard is $80 \%$, while the acquisition is $96 \%$.
\end{abstract}

Keywords: Using English songs improves mastery of English vocabularies

\begin{abstract}
A B S T R A K
Penelitian ini bertujuan untuk meningkatkan hasil belajar siswa dalam pembelajaran Bahasa Inggris dengan menggunakan media lagu-lagu Bahasa Inggris. Subjek penelitian ini adalah siswa kelas VIII-2 SMP Negeri 2 Mardingding, Kecamatan Mardingding, Kabupaten Karo yang berjumlah 27 Orang terdiri dari 11 orang siswa laki-laki dan 16 orang siswa perempuan. Metode penelitian yang diterapkan adalah metode penelitian tindakan kelas. Melalui dua siklus pembelajaran, setiap siklus dilakukan kegiatan perencanaan, pelaksanaan, pengamatan dan refleksi. Berdasarkan hasil analisis data diketahui bahwa dengan menggunakan media lagu-lagu Bahasa Inggris pada pelajaran Bahasa Inggris di kelas VIII-2 SMP Negeri 2 Mardingding, Kecamatan Mardingding, Kabupaten Karo Tahun Pelajaran 2015/2016, penguasaan vocabularies siswa mengalami peningkatan dari Siklus Pertama ke Siklus Kedua. Penguasaan vocabularies siswa pada siklus pertama memperoleh nilai rata-rata 30 dengan persentase skor Perolehan terhadap skor total sebesar 30\% dan ini termasuk kategori sangat kurang ( tidak baik). Dan jauh dari kkm (70). Pada siklus kedua penguasaan vocabularies siswa memperoleh nilai rata-rata 80 dengan persentase skor Perolehan terhadap skor total $80 \%$ dan ini termasuk dalam kategori baik, dan sudah melampaui kkm (70). Jadi, peningkatan penguasaan vocabularies siswa dari siklus I ke siklus II sebesar 50\% sedangkan untuk hasil belajar siswa setelah digunakan media lagu-lagu Bahasa Inggris pada pembelajaran Bahasa Inggris juga mengalami peningkatan. Demikian juga dengan
\end{abstract}


jumlah siswa yang tuntas KKM, sudah mencapai indikator keberhasilan, di mana standar yang ditetapkan $80 \%$, sedangkan perolehan mencapai $96 \%$.

Kata Kunci: Menggunakan lagu-lagu Bahasa Inggris meningkatkan penguasaan vocabularies Bahasa Inggris. 


\section{PENDAHULUAN}

\section{A. Latar Belakang Masalah}

Pembelajaran merupakan suatu kegiatan yang melibatkan seseorang untuk memperoleh pengetahuan, keterampilan dan nilai-nilai positif dengan memanfaatkan sumber-sumber belajar. Pembelajaran dapat melibatkan dua pihak yaitu siswa sebagai pembelajar dan guru sebagai fasilitator. Yang terpenting dalam kegiatan pembelajaran adalah terjadinya proses belajar ( learning process). Hasil belajar dikatakan dapat berhasil jika memenuhi beberapa ciri berikut :

1. Belajar sifatnya disadari. Dalam hal ini siswa merasa dirinya sedang belajar, timbul dalam dirinya motivasi-motivasi untuk memiliki pengetahuan yang diharapkan sehingga tahapan-tahapan dalam belajar sampai pengetahuan itu dimiliki secara permanen (retensi) dan betul-betul disadari sepenuhnya.

2. Hasil belajar diperoleh dengan adanya proses. Dalam hal ini pengetahuan diperoleh tidak secara spontanitas ( instant), namun bertahap ( sequensial).

Peranan guru dalam proses pembelajaran sangat penting karena seorang guru harus merancang, melaksanakan, dan mengevaluasi pembelajaran yang dilakukannya. Tahap merancang pembelajaran merupakan tahap yang menentukan keberhasilan dari suatu pembelajaran yang akan dilakukan. Pada tahap ini seorang guru harus membuat rencana secara detail, apa dan bagaimana pembelajaran yang akan dilakukannya di dalam kelas. Rencana pembelajaran yang baik kemungkinan besar akan memberikan peluang dan hasil yang baik. Dalam membuat perencanaan ini hal penting yang perlu diperhatikan adalah perencanaan pembelajaran yang memungkinkan siswa dapat membangun minat belajar dan aktif membangun pengetahuannya sendiri dan bukan didiktekan oleh guru. Hal ini sesuai dengan pandangan konstruktivisme dalam pembelajaran (Bodner 1986).

Kelemahan dalam merancang pembelajaran yang tidak sesuai dengan karakteristik mata pelajaran akan berakibat pada hasil pelaksanaan pembelajaran di kelas. Oleh karena itu usaha-usaha dilakukan untuk merancang pembelajaran yang sesuai dengan karakteristik mata pelajaran dan keadaan siswa untuk meningkatkan mutu pendidikan. Namun dalam upaya meningkatkan mutu pendidikan tersebut guru tentu pernah menghadapi permasalahan dalam kegiatan pembelajaran di kelas. Permasalahan itu dapat berkaitan dengan proses maupun hasil belajar. Menurut Siswandi (2008 : 11), permasalahan pembelajaran bukan saja ada pada siswa, tetapi bisa pula berkenaan dengan fasilitas belajar, sistem evaluasi guru, dan bahkan sekolah. Permasalahan yang berkaitan dengan siswa, misalnya adalah kurangnya minat baca dan motivasi belajar, ketidakberanian bertanya, kekurangterampilan dalam berbicara, cepat dan efektif, dan kekurangterampilan dalam mengarang.

Berkenaan dengan permasalahan di atas, guru memiliki tanggung jawab untuk mengurangi dan bahkan memecahkan masalah tersebut. Guru hendaknya berupaya untuk mencari jalan keluar atas permasalahan yang ada. Kesadaran atas tanggung jawab itu diharapkan dimiliki oleh guru karena pada hakikatnya tidak ada seorangpun dari guru yang menginginkan siswanya gagal dalam belajar. Guru tentu mengharapkan agar para peserta didiknya dapat belajar secara optimal.

Dalam pembelajaran bahasa Inggris ada empat aspek keterampilan berbahasa, yakni mendengarkan, berbicara, membaca, dan menulis. Siswa akan mengalami kesulitan pembelajaran apabila kurang dalam penguasaan kosakata. Selain itu, penulis 
sering mendapati siswanya mengalami kesulitan dalam mencapai suatu kompetensi dasar. Hal ini dikarenakan penguasaan kosakata bahasa Inggris siswa kurang memadai, sehingga sangat mengganggu pencapaian kompetensi seperti yang tertera dalam kurikulum, sehingga proses pencapaian suatu kompetensi dasar akan berjalan lebih lama.

Banyak cara yang dapat dilakukan guru untuk mengatasi dan memecahkan permasalahan tersebut. Dengan bertitik pada uraian di atas, penulis mengambil judul "Meningkatkan Penguasaan Vocabularies Siswa Melalui Lagu - Lagu Bahasa Inggris di Kelas Vlll-2 SMP Negeri 2 Mardingding Semester Ganjil Tahun Pelajaran 2015/2016”.

Berdasarkan latar belakang masalah, maka rumusan masalah yang dikemukakan dalam penelitian ini adalah: (1) Bagaimanakah cara meningkatkan penguasaan vocabularies siswa dalam pelajaran bahasa inggris pada siswa kelas Vlll-2 di SMPN 2 Mardingding pada semester ganjil tahun pelajaran 2015 / 2016? Dan Apakah menggunakan lagu-lagu bahasa inggris dapat meningkatkan penguasaan vocabularies siswa kelas Vlll-2 di SMPN2 Mardingding pada semester ganjil tahun pelajaran 2015 / 2016 ? 


\section{KAJIAN PUSTAKA}

\section{A. Deskripsi Teori}

1. Vocabularies (kosakata)

Kosakata (vocabulary), didefinisikan secara luas, adalah pengetahuan tentang kata-kata dan makna kata. Namun, definisi ini tidak secara luas, karena menyangkut beberapa perbedaan penting. Pertama dari semua, kata datang baik dalam bentuk lisan dan tertulis, dan kata-kata yang digunakan dalam berpidato sering kurang tepat dan lebih terbatas, dibandingkan dengan kata-kata yang digunakan dalam media cetak. Hayes dan Ahrens (1988) menemukan bahwa per 1000 kata, banyak kata yang jarang digunakan oleh anak-anak, buku $(30,9)$ dan koran $(68,3)$ dibandingkan di acara televisi dewasa $(22,7)$, ahli keterangan saksi $(28,4)$, atau lulusan perguruan tinggi berbicara dengan teman-teman mereka $(17,3)$.

Selain itu, pengetahuan tentang kata bukanlah Fenomena semua-atau-tidak (Beck dan McKeown 1991). Anda mungkin mengenali aspek dari sebuah kata ketika Anda mendengar atau membaca tapi tidak merasa nyaman menggunakannya dalam menulis atau pidato Anda sendiri.

Perbedaan ini biasanya disebut sebagai perbedaan antara reseptif dan ekspresif (atau produktif) kosakata. Kosakata reseptif biasanya lebih besar daripada ekspresif kosa kata.

Vocabularies atau kosa kata adalah salah satu hal penting yang perlu dipahami untuk mempelajari bahasa. Karena tanpa memahami kosa kata, akan mempersulit kita dalam pembelajaran. Dalam Kamus Besar Bahasa Indonesia, kosa kata adalah perbendaharaan kata. Sedangkan arti dari kata itu sendiri adalah unsur bahasa yang diucapkan atau dituliskan yang merupakan perwujudan kesatuan perasaan dan pikiran yang dapat digunakan dalam berbahasa.

Dalam percakapan sehari-hari kita berbicara tentang kosa kata di bentuk tunggal; kita berbicara tentang kosakata seseorang. Ini sebenarnya merupakan penyederhanaan yang berlebihan. Orang Amerika di dalam Heritage Dictionary mendefinisikan kosakata sebagai "jumlah kata-kata yang digunakan oleh, dipahami oleh, atau diperintah dari seseorang atau kelompok tertentu. "Dalam hal ini kita prihatin dengan jumlah kata-kata yang digunakan dan dipahami oleh siswa.

Pendidikan adalah proses pengubahan sikap dan tata laku seseorang atau kelompok orang dalam usaha mendewasakan manusia melalui upaya pengajaran dan pelatihan. Kurikulum yang digunakan dewasa ini berorientasi pada kompetensi tertentu atau kecakapan sebagai hasil proses pembelajaran di sekolah.

Bahasa Ingggris berfungsi sebagai alat untuk berkomunikasi dalam rangka mengakses informasi, selain sebagai alat untuk membina hubungan interpersonal dan bertukar informasi. Kemampuan berkomunikasi dalam bahasa Inggris, baik dalam bentuk lisan atau tulisan yang meliputi kemampuan mendengarkan ( listening), berbicara (speaking), membaca (reading), dan menulis (writing).

Salah satu komponen pembelajaran bahasa adalah pemahaman kosa kata dari bahasa Ingggris itu sendiri, di samping komponen - komponen lainnya. Dari Wikipedia, kosa kata (Inggris : vocabulary) adalah himpunan kata yang diketahui oleh seseorang atau entitas lain, atau merupakan bagian dari suatu bahasa tertentu. Kosa kata seseorang didefinisikan sebagai himpunan semua kata-kata yang dimengerti oleh orang tersebut atau semua kata - kata yang kemungkinan akan digunakan oleh orang tersebut untuk 
menyusun kalimat baru. Kekayaan kosa kata seseorang secara umum dianggap merupakan gambaran dari intelejensia atau tingkat pendidikannya.

Penambahan kosa kata seseorang secara umum dianggap merupakan bagian penting, baik dari proses pembelajaran suatu bahasa ataupun pengembangan kemampuan seseorang dalam suatu bahasa yang sudah dikuasai. Di sekolah, murid diajarkan kata - kata baru sebagai bagian dari mata pelajaran tertentu dan banyak pula orang dewasa yang menganggap pembentukan kosa kata sebagai suatu kegiatan yang menarik dan edukatif.

\section{B. Lagu}

Lagu telah menjadi pendamping yang menyenangkan bagi manusia selama atau bahkan lebih lama dari yang kita dapat berbicara. Sebagai bagian integral dari pengalaman bahasa kita, itu bisa menjadi nilai besar untuk pengajaran bahasa asing. Dan banyak-faceted manfaat lagu yaitu memperkaya dan mengaktifkan kelas bahasa asing kami. Georgi Lozanov menggabungkan musik ke dalamnya mengajar metodeSuggestopedia, untuk musik instrumental dalam menciptakan lingkungan yang santai dan nyaman, yang dapat mendorong pembelajaran bahasa (Larsen-Freeman, 1985). Selain musik, elemen tak terpisahkan lagi dari lagu ini lirik yang berfungsi sebagai sumber asli langsung dari bahan ajar di kelas bahasa asing, jadi mengapa lagu harus diabaikan oleh guru? Ada penelitian yang berlimpah di luar negeri pada lagu sebagai sumber ajaran otentik di pengajaran bahasa (Maley, 1997; Eken, 1996; Gaston, 1968; Geoff, 2003), tetapi kekurangan penelitian tersebut dilaporkan di Cina.

Lagu merupakan gubahan seninada atau suara dalam urutan,kombinasi,dan hubungan temporal yang biasanya diiringi dengan alat musik. Bernyanyi adalah melafalkan syair sesuai nada, ritme, dan melodi tertentu hingga membentuk harmoni. Orang dapat bernyanyi dengan lancar apabila ia dapat melapalkan dan mengingat kata demi kata yang terdapat dalam lagu. Semakin sering sebuah lagu dinyanyikan maka semakin mudah melafalkan dan mengingat kata - kata dalam lagu itu. Bahasa inggris bukanlah bahasa pengantar di Indonesia, hal ini menyebabkan siswa merasa kesulitan dalam melafalkan dan mengingat kosakata dalam bahasa inggris.

\section{Lagu bahasa Inggris Memfasilitasi Pembelajaran Bahasa Inggris}

"Mengajar Bahasa dapat didefinisikan sebagai kegiatan yang dimaksudkan untuk membawa pembelajaran bahasa" (Stern, 1983, hal.21). Oleh karena itu, apa pun teori pengajaran bahasa harus dimulai dari proses pembelajaran atau perspektif pembelajar.

\section{C.1. Implikasi Psikologis}

"Konsep belajar, seperti yang dipahami saat ini, sangat dipengaruhi oleh studi psikologis proses belajar. Bagian ini menunjukkan efektivitas mengintegrasikan lagu bahasa Inggris ke ELT (English Language Teaching) dari teori otak manusia, yang merupakan markas dari pengolahan bahasa.

\section{C.1.1. Multiple Intelligence dan mendengarkan lagu-lagu bahasa Inggris}

Teori Multiple Intelligence (MI), diusulkan dan dikembangkan oleh Gardner (1993), menunjukkan bahwa ada nomor dari jenis yang berbeda dari kecerdasan yang dimiliki oleh masing-masing individu dalam berbagai derajat. Sesuai dengan MI, 
manusia intelijen dikategorikan menjadi sedikitnya sembilan jenis utama: lisan / kecerdasan linguistik, matematis / logis kecerdasan visual / spasial intelijen, badan / kecerdasan kinestetik, musikal / kecerdasan ritmik, kecerdasan interpersonal, kecerdasan intrapersonal, kecerdasan naturalis dan kecerdasan eksistensial, yang semuanya tidak terisolasi dan tidak relevan, tapi saling bergantung dan saling melengkapi satu sama lain. Oleh karena itu, tidak pantas untuk mengeksplorasi hanya satu jenis kecerdasan dalam belajar EFL. Verbal / linguistik intelijen, musik / kecerdasan ritmik, interpersonal, intelijen, badan / kecerdasan kinestetik dan bahkan lebih dapat berkontribusi untuk mengembangkan dan melengkapi pelajar dengan kompetensi linguistik dan meningkatkan kemampuannya belajar bahasa asing. Mendengarkan lagulagu bahasa Inggris adalah besar Nilainya untuk memanfaatkan potensi linguistik pembelajar melalui mempesona melodi, berbagai ritme dan gambar-membangkitkan lirik, yang menarik bagi perkembangan multidimensi kecerdasan manusia.

\section{C.1.2. Fungsi membelah dalam bahasa}

Penelitian tentang psikolinguistik mengungkapkan bahwa lagu dapat mengaktifkan akuisisi bahasa dan pembelajaran di kedua belahan otak manusia (Carroll, 2000; Larsen-Freeman dan Long, 2000; Williams dan Burden, 1997). Melalui psikolog ' Penelitian terus-menerus di telinga dan belahan berfungsi untuk menemukan perbedaan, penemuan yang keluar dari telinga kanan, mengarah ke kiri belahan (LH), mengambil keuntungan mencolok di telinga kiri untuk rangsangan pidato, sehingga "LH tampaknya memiliki sebuah bawaan yang sangat khusus yaitu linguistik mekanisme "yang mengasumsikan tanggung jawab utama dari pengolahan analitik bahasa (Carroll, 2000, p.349). Namun, fungsi penting belahan kanan dalam pengolahan bahasa tidak bisa diabaikan. Telinga kiri, yang mengarah ke belahan kanan, adalah tajam untuk suara nonverbal seperti melodi dan warna emosional pesan. Lagu memasuki otak manusia dari belahan telinga kiri ke kanan dengan cara yang agak berbeda. Dalam berpidato bagian belahan kanan berperan dalam pengolahan bahasa dan menjadi lebih aktif dalam menggalang arti keseluruhan rumusan pidato (Ellis, 1985). "Pidato diformulasikan terdiri dari ekspresi yang dipelajari sebagai keseluruhan unanalysable dan digunakan pada acara-acara tertentu "(Lyons, 1968, p.177).

\section{C.2. Stimulasi pembelajaran afektif dengan lagu}

Menggunakan lagu bahasa Inggris di kelas EFL (English Foreign Learner) dapat membuat pembelajaran lebih menyenangkan, mengurangi kecemasan siswa, membina kepentingan mereka dan memotivasi mereka untuk mencapai tujuan belajar bahasa. Siswa akan menganggap lagu bahasa Inggris sebagai bagian dari hiburan yang menyenangkan dan memudahkan mereka untuk belajar bahasa Inggris dan dengan demikian mereka menemukan cara belajar bahasa Inggris melalui lagu-lagu lebih mudah dan santai.

\section{C.2.1. Hipotesis filter yang efektif}

Pada tahun 1982, "Dulay et al. menyarankan bahwa penggunaan filter tergantung pada faktor-faktor afektif seperti motivasi pelajar, sikap dan emosi "(Ellis, 1985, p.297). Dan kemudian Krashen mengembangkan Hipotesis Affective Filter berdasarkan cara pandang Titik Dulay . Krashen (1985) mengemukakan bahwa belajar afektif akan terjadi ketika filter afektif lemah. Kapan 
pelajar dikatakan dalam keadaan afektif, ketika sang pelajar sangat termotivasi, percaya diri dan santai, filter akan lemah dan memungkinkan mereka menerima banyak masukan, dan bersikap positif terhadap pembelajaran. Sebaliknya, filter akan menjadi lebih kuat ketika pelajar dihantui dengan motivasi yang rendah, kurangnya kepercayaan diri dan kecemasan yang tinggi. Dalam hal ini, pelajar tidak siap akuisisi bahasa atau belajar. Itu Afektif Filter Hipotesis menunjukkan bahwa guru yang ideal harus mampu memberikan suasana kelas kondusif untuk memotivasi, mendorong siswa dan mengurangi kecemasan mereka jika ada.

\section{C.2.2. Kecemasan}

Kecemasan, terkait dengan perasaan negatif, seperti marah, ketegangan, frustasi, keraguan diri dan rasa takut, akan menghambat pembelajaran bahasa (Larsen-Freeman, 2000). Siswa luar pubertas lebih cenderung dipengaruhi oleh kecemasan dalam belajar bahasa asing. Oleh karena itu, untuk meminimalkan jumlah kecemasan di pembelajar bahasa asing menjadi penting untuk mencapai kesuksesan dalam belajar bahasa.

\section{C.2.3. Gairah motivasi dengan lagu-lagu bahasa Inggris}

Motivasi merupakan unsur penting dalam belajar afektif. Williams dan Beban (1997, p.129) menguraikan motivasi sebagai "negara kognitif dan emosional gairah, yang mengarah ke keputusan sadar untuk bertindak, dan yang menimbulkan periode berkelanjutan dalam upaya meningkatkan intelektual dan / atau fisik untuk mencapai tujuan yang telah ditetapkan sebelumnya ". Motivasi dapat dipicu oleh salah satu penyebab internal seperti bunga pelajar, antusiasme dan keinginan atau oleh pengaruh eksternal seperti tekanan teman sebaya.

Banyak lagu bahasa Inggris, terutama lagu-lagu pop yang cukup populer di kalangan orang-orang muda Cina, seperti Jingle Bells, Right Here Waiting, My Heart akan Pergilah dan Big Big World. Untuk satu hal, lagu-lagu bahasa Inggris mempekerjakan tema yang menarik bagi orang-orang muda, seperti perayaan liburan, kenangan masa kecil, cinta dan persahabatan; dan untuk yang lain, banyak siswa ingin belajar lagu-lagu bahasa Inggris, karena mereka ingin model diri pada bintang Hollywood dan penyanyi atau meningkatkan status mereka di antara rekan-rekan. Semakin besar keinginan mereka, semakin cepat mereka belajar. Ketika mereka belajar dengan cepat dan terus membuat kemajuan, mereka akan lebih percaya diri, sangat termotivasi dan dikhususkan untuk tugas belajar.

\section{C.2.4. Pengaruh Pembelajaran afektif}

Belajar afektif juga belajar yang efektif. Menurut psikolinguistik, afektif adalah keterlibatan dengan bahasa yang bisa "Merangsang penggunaan yang lebih lengkap dari sumber daya otak", menghidupkan kembali "jalur saraf antara daerah otak" dan memperdalam pengolahan multidimensi bahasa (Bolitho et al., 2003, p.256). Melalui pembelajaran afektif, kapasitas pelajar untuk belajar akan diperluas dan dimana hasil yang tidak diharapkan akan diproduksi.

\section{C.3. Lagu dapat meningkatkan kesadaran bahasa}

Kesadaran bahasa adalah "sarana untuk membantu peserta didik untuk membantu diri mereka sendiri". Hasil meningkatkan kesadaran bahasa " tidak akan hanya dalam penggunaan bahasa, tetapi juga penggunaan bahasa yang lebih 
sensitif terhadap isu-isu budaya, identitas dan ekuitas "(ibid, p.254). Lagu berfungsi sebagai sumber dari penggunaan bahasa yang sasarannya membantu meningkatkan kesadaran bahasa siswa dalam belajar bahasa Inggris sebagai bahasa asing.

\section{C.3.1. Definisi kesadaran bahasa}

"Kesadaran Bahasa adalah atribut mental yang berkembang untuk memotivasi pelajar dalam menambah wawasannya dan mempelajari bagaimana bahasa itu bekerja secara bertahap. "(ibid, p.251). Tomlinson (1994, p.123) memandang kesadaran bahasa sebagai "dinamis dan intuitif", yang "secara bertahap dikembangkan secara internal oleh pelajar".

\section{C.3.2. Lagu-lagu dan kesadaran bahasa}

Siswa yang sungguh-sungguh belajar, menyanyikan, mendengarkan lagu-lagu bahasa Inggris dapat terdorong untuk mempelajari bahasa tersebut. Mereka harus lancar melafalkan kata-kata bahasa Inggris yang terdapat dalam lagu itu sebelum mereka dapat menyanyikan sendiri lagu tersebut. Oleh karena itu, mereka didorong untuk mengetahui bagaimana setiap suara diucapkan dan bagaimana semua suara yang dirantai bersama-sama, sehingga dapat menyampaikan makna kata dalam lagu itu. Di proses ini, kesulitan yang ditemui peserta didik dalam menyanyikan lagu-lagu bahasa Inggris akan memungkinkan mereka untuk melihat kesenjangan antara kinerja aktual mereka dalam memahami makna bahasa yang disampaikan penyanyi asli. "Memperhatikan hal ini dapat memberikan arti-penting untuk fitur, untuk masukan ke depan, dan memberikan kontribusi untuk kesiapan psikologis pelajar dalam memperoleh fitur yang tepat "(Bolitho et al., 2003, hal.252). Selain itu, meskipun sebagian besar siswa menganggap mendengarkan serta belajar lagu-lagu bahasa Inggris sebagai hiburan, mereka juga belajar secara implisit dan tidak sadar, yang merupakan cara yang jauh lebih menyenangkan dan efisien untuk meningkatkan kesadaran bahasa, mekanik menghafal dari buku kosa kata dan tata bahasa tentu saja membosankan. "Kesadaran Bahasa tidak diajarkan oleh guru atau dengan kursus-buku; itu dikembangkan oleh pelajar. kesadaran bahasa adalah internal bertahap,realisasi dari realitas penggunaan bahasa.

\section{Memanfaatkan Lagu Bahasa Inggris di Kelas English Foreign Learner}

Seperti ditunjukkan di atas, teori MI, fungsi belahan, kesadaran bahasa dan manfaat intrinsik lagu memiliki semua pendukung dalam memanfaatkan lagu bahasa Inggris di ELT. Hal berikutnya yang membutuhkan perhatian kita adalah bagaimana membawa nilai pendidikan dari lagu bahasa Inggris di kelas EFL. Beberapa praktek tertentu diadopsi oleh peneliti yang direkomendasikan di sini sebagai upaya awal untuk mengintegrasikan lagu bahasa Inggris ke bahasa mengajar dengan berbagai aspek bahasa yaitu keterampilan-menyimak, berbicara, kosakata, tata bahasa dan menulis dalam pengajaran bahasa Inggris.

\section{D.1. Dalam mendengarkan}

Sebuah pemahaman pendengaran yang baik memberikan sudut-batu untuk mengembangkan keterampilan lain dalam belajar bahasa asing. Tapi itu juga yang paling sulit di antara semua keterampilan bahasa untuk pemula untuk menguasai. Saat 
mendengarkan penutur asli, di sebagian besar kasus kita menemukan ucapan mereka berjalan lancar seperti sungai, bahkan sangat cepat, sehingga EFL peserta didik mungkin gagal untuk menangkap dan memahami kata-kata yang mereka ucapkan. Sebuah pembenaran untuk ini adalah bahwa peserta didik telah terlalu lama terbiasa untuk berbicara kata demi kata tanpa mengurangi, penghubung, hilangnya ledakan dan sebagainya yang cukup umum dalam pidato biasa penutur asli ini. Penutur asli berbicara kata demi kata hanya dalam keadaan khusus, seperti berbicara dengan bayi. Misalnya, beberapa penutur asli akan mengatakan "tidak sama sekali "sebagai transkripsi fonetik yang kamus memiliki offered- / n t AET SL /. Paling sering daripada tidak, mereka mengatakan / n t TSL/. Tidak hanya konsonan dan vokal berikut direkatkan seperti yang kita sebut penghubung, tetapi / $\mathrm{t} /$ juga disuarakan, yang membuat terdengar seperti / d /, dan / æ $\mathrm{t} /$ direduksi menjadi / $\mathrm{t} /$.

Mendengarkan lagu-lagu bahasa Inggris akan mempersiapkan peserta didik EFL harus berhadapan dengan bahasa Inggris asli. Guru dapat merencanakan latihan khusus untuk membantu siswa dalam meningkatkan pemahaman mendengarkan mereka. Sebuah tugas dalam bentuk gap-fill dapat digunakan untuk membantu siswa melihat dan menyerap realitas fonetik dalam pidato penutur asli bahasa Inggris '. Sebagai salah satu contoh kita ambil lagu populer Big Big World.

\section{Big Big World}

I can see the first falling it's all yellow and nice

It's so very cold like the way I'm feeling

I'm a big big in a big big ; it's not a big big thing if you leave me.

But__do do feel that do do will, уои much,

you much...

it's now raining and

Why did it have to

I'm a big big falling from my eyes in a big big

But__do do feel that

you much... I have

But when I my do do will, ; it's not a big big thing if you leave me.

(keys: leaf, outside, inside, girl, world, I, I, miss, miss, Outside, tears are, happen, end, girl, world, I, I, miss, miss, my arms, warm, open, eyes)

Lirik yang pertama kali disajikan dihapus bagian-bagian tertentu. Setelah menikmati lagu, siswa diminta untuk mengisi kata-kata yang kosong sesuai yang mereka dengar. Kata-kata yang kosong diambil off tidak acak tetapi dengan niat. Kebanyakan dari mereka telah mengalami sedikit perubahan dalam suara, sehingga tidak mudah bagi siswa untuk mengenali dan memahami kata-kata yang didengar. Perubahan mematuhi aturan fonologi yang sadar digunakan oleh penutur asli dalam pidato biasa tetapi sering diabaikan oleh peserta didik EFL. Misalnya, kata "daun" di kosong pertama telah kehilangan konsonan akhir / $/$ / karena diikuti kata "jatuh" yang dimulai dengan huruf / $\mathrm{f}$ /. Kata "akhir" dalam kosong kedua, garis keenam keliru ditangkap oleh banyak siswa untuk "saat", meskipun mereka bingung dengan makna dan struktur "mengapa itu semua harus saat". Itu alasannya adalah bahwa batas penyisipan telah terjadi antara dua kata "to" dan "akhir". A meluncur / w / sisipan antara bulat vokal / u / dan vokal unrounded / 
e / (Chomsky, 1968). Selain itu, pada kesempatan yang paling akhir / d / tidak dapat mendengar karena kerugiannya ledakan. Itulah mengapa banyak siswa membuat kesalahan di sini. Latihan ini dapat sangat membantu karena hanya ketika pengucapan alam dan semua aturan fonologi menjadi terinternalisasi bagi pembelajar sehingga mereka dapat secara bertahap mengejar ketinggalan dengan pidato penutur asli '. Internalisasi aturan fonologi ini menuntut koordinasi kedua langkah-berbicara bagi peserta didik EFL.

\section{D.2. Dalam berbicara}

Lagu dapat digunakan untuk mengajarkan pengucapan alam secara efisien. Pengucapan penyanyi asli 'menyediakan model untuk peserta didik EFL. Kita bisa dengan mudah menemukan lagu-lagu yang dinyanyikan oleh salah satu penyanyi Amerika, Inggris, Kanada atau Australia dan membiarkan peserta didik memilih pengucapan yang ingin mereka tiru. Mendengarkan dan mempelajari lagu-lagu bahasa Inggris berulang-ulang, secara bertahap akan memperbaiki kesalahan mereka dalam mencapai pengucapan seperti penutur asli.

Selain itu, untuk menyanyikan lagu bahasa Inggris dengan baik juga menuntut pemahaman tentang sejumlah aturan fonologi yang disebutkan di atas. Misalnya, penghubung, hilangnya ledakan, asimilasi, menyuarakan, penghapusan, penyisipan dan sebagainya adalah fenomena yang paling umum terjadi hampir di setiap lagu bahasa Inggris. Untuk menggambarkan aturan fonologi di terminologi linguistik bisa menjadi tugas yang abstrak dan halus, tapi lagu-lagu bahasa Inggris berfungsi sebagai media melalui mana aturan-aturan ini dapat dibuat beton dan diakses. Peserta didik EFL akan mendapatkan pemahaman dengan menginternalisasi mereka melalui pengulangan dan peniruan. Dalam kelas eksperimen, peneliti diajarkan mengungkapkan bahwa siswa yang selalu mendengarkan lagu-lagu bahasa Inggris akan lebih mudah memperhatikan pengucapan, aturan fonologi, stres dan intonasi dari yang lain dan dengan demikian mereka mengucapkan kata-kata lebih tepat dan berbicara bahasa Inggris lebih lancar.

\section{D.3. Dalam Menghafal kosa kata, struktur dan tata bahasa}

Ketika mendengarkan sebuah lagu yang mengesankan, sebagian besar peserta didik yang ingin lebih memahami apa yang penyanyi ekspresikan akan mencoba menyanyikannya sendiri lagu tersebut. Dengan motivasi seperti itu, peserta didik akan merasa terkejut mereka bisa mengingat semua kata-kata yang muncul dalam lirik, bahkan kata-kata yang sulit. Lagu kartun terkenal di Disney "Lion King" -Bisa Anda Rasakan Love Tonight-selalu cincin di telinga peserta didik. Beberapa kata dan frase yang muncul dalam lirik memang sulit seperti menyerah, gelandangan, memutar kaleidoskop, voyager bernasib sial, dan pengembara mata terbelalak. Tapi untuk mengajar kata-kata ini dalam konteks melodi muncul lebih mudah dan lebih efektif.

Sifat lagu cukup berulang-ulang dan konsisten. Misalnya, Lemon Tree-lagu pop sangat akrab menyediakan banyak kesempatan bagi siswa untuk fokus pada studi tentang progresif tegang hadir dalam tata bahasa Inggris. "Saya sedang duduk di sini di ruang membosankan "," Aku membuang-buang waktu saya "," Aku berkeliaran, aku menunggumu "," aku berkeliling di mobil saya. Aku mengemudi terlalu cepat, aku mengemudi terlalu jauh "," Aku memutar kepala atas dan ke bawah, aku berubah berbalik memutar balik terbalik "," Aku melangkah di dalam gurun sukacita "dan 
sebagainya. Setelah mendengarkan lagu ini, siswa akan dengan mudah menghafal kalimat-kalimat sederhana, cenderung menggunakannya dalam percakapan mereka sendiri dan bahkan benar memproduksi sendiri hukuman progresif pada waktu sekarang.

Lagu tidak selalu terdiri dari struktur kalimat sederhana atau tata bahasa. Sebagai contoh, berikut lagu Janji Jangan Come Easy berfungsi sebagai teladan untuk mengajar mood subjungtif, salah satu yang paling sulit dan membingungkan poin tata bahasa bagi siswa dalam belajar bahasa Inggris. Misalnya, "Saya seharusnya tahu selama ini", tapi "Aku", dalam lirik, sebenarnya tidak menyadari di awal bahwa ada sesuatu yang salah dalam hubungan cinta nya. Bagian ini menyajikan siswa dengan gambaran yang jelas tentang dunia batin seseorang jatuh cinta, di mana mereka dapat dengan mudah menangkap mood dan isi hati penulis lagu yang bermaksud menyampaikan, suasana hati secara tidak sadar.

\section{Promises Don't Come Easy}

I should have known all along

there was something wrong

I just never read between the lines

then I woke up one day and found you way

leaving nothing but my heart behind

what can I do to make it up to you

Listening to English songs easily embed new vocabulary and grammatical structures in learner's both conscious and unconscious memory. Its unexpected teaching effects will startle you!

\section{D.4. Menulis Kreatif}

Mendidik peserta didik EFL secara monoton dan serius sering tidak memberikan hasil yang diharapkan. Jadi mengapa tidak sesekali membuat tulisan menyenangkan di kelas dengan menciptakan sesuatu yang baru? Dalam penulisan kreatif lagu, siswa didorong untuk menciptakan lirik mereka sendiri dengan mengikuti lagu yang sama dan meniru format garis liris lagu asli. Versi berikut "Baby, Do not Cry" ditulis ulang oleh salah satu siswa dari lagu "Que Sera, Sera".

\section{$\underline{B a b y, \text { Don't Cry }}$}

When I was just a little girl

I dreamed of beauty

I dreamed of fame

I wanna marry a rich handsome man

But reality drove me mad

"Oh, baby, don't cry,"

My mother told me that,

"The future will not be so bad.

Oh, baby, don't cry.

Like a bird you'll fly."

Forget

Forget ...forget....forget....forget

Forget your task

Remember...remember...remember..remember

Remember your school

\section{Que Sera Sera}

When I was just a little girl,

I asked my mother,

"What will I be?

Will I be pretty, will I be rich?"

Here's what she said to me:

"Que Sera, Sera.

Whatever will be, will be.

The future's not ours to see.

Que Sera, Sera.

What will be, will be." 
Obey the rule, Do your task, Study agen

Do your task, obey the rule, study again

Jelas, versi meniru lagu baru dari lagu asli dalam bentuk seperti kedua mencakup percakapan antara ibu dan putrinya dan kemudian berakhir dengan kata menenangkan ibu. Namun, siswa membawa sesuatu yang baru di konten. Versi baru berfokus pada kekecewaan putri untuk impian masa kecil bukan pertanyaan tentang masa depan ketika dia hanya seorang gadis kecil. Penggunaan struktur paralel, ekspresi idiomatik dan sajak di Baby versi baru, Do not Cry semua memanifestasikan kreativitas siswa, imajinasi serta kemampuan menulis bahasa Inggris. Dan lagu ketiga merupakan percakapan antara guru dan siswa yang mengingatkan siswa agar mematuhi peraturan sekolah, mengerjakan tugasnya dan mengulangi pelajaran di rumah ( obey the rule, do your task, study agen) supaya pendidikannya berhasil.

Oleh karena itu, menulis lirik oleh imitasi mungkin cara mujarab menggali kreativitas EFL (English Foreign Learner) dalam bahasa. Itu merupakan contoh lagu yang tepat digunakan dalam pembelajaran bahasa Inggris dalam meningkatkan, membangkitkan empati, merangsang inspirasi dan menyalakan semangat untuk mengekspresikan pengalaman dan emosi mereka dengan cara yang sama.

Peranan lagu-lagu dalam pembelajaran bahasa Inggris

1. Meningkatkan daya ingat, pemahaman, pelafalan kosa kata.

2. Membantu para guru untuk menciptakan pembelajaran yang aktif, kreatif, dan menyenangkan.

Berikut ini fungsi dari lagu seperti yang dijelaskan oleh Montolalu et al (2008 : 3 : 23) :

1. Meningkatkan kreativitas dan daya imajinasi. Musik berperan sebagai stimulan setiap kali ada memerlukan peningkatan kreativitas dalam kehidupan.

2. Meningkatkan kecerdasan. Dengan mendengarkan nyanyian kita bisa meningkatkan kecerdasan dan prestasi anak di sekolah.

3. Nyanyian merupakan salah satu cara penting untuk meningkatkan daya ingat.

Banyak cara yang bisa dilakukan untuk peningkatan vocabularies siswa. Salah satunya adalah dengan cara menggunakan lagu - lagu bahasa Inggris. Bernyanyi adalah cara yang menyenangkan untuk belajar kosa kata.

\section{Kerangka Berpikir}

Sesuai dengan tuntutan pencapaian tujuan pembelajaran bahasa Inggris, yaitu dapat berkomunikasi secara lisan maupun tulisan, maka para siswa dituntut untuk memiliki pemahaman kosa kata yang memadai sehingga mereka akan dapat berkomunikasi dengan baik dalam berbagai konteks dan tema.

Aktifitas pembelajaran berbasis bahasa secara mendasar dan akan bergantung pada pemahaman siswa akan kosa kata tersebut. Para siswa harus mempunyai akses pada makna kata yang digunakan oleh guru dan lingkungan sekitarnya. Keterbatasan pemahaman kosa kata pada siswa akan mengakibatkan terhambatnya pencapaian kompetensi berbahasa. Bagaimanapun pembelajaran itu sendiri bergantung pada siswa. Kurangnya pemahaman kosa kata adalah penyebab utama dari kegagalan akademik yang dialami siswa. 
Pemahaman vocabulary siswa kelas VIII-2 SMPN 2 Mardingding masih di bawah pemahaman minimal yang harus dimiliki siswa. Menurut Soemanto ( $2006: 113$ ), ada tiga faktor yang mempengaruhi belajar, yaitu:

1. Faktor - faktor stimuli belajar.

2. Faktor - faktor metode belajar.

3. Faktor - faktor individual.belajar siswa. Masalah memotivasi siswa dalam belajar, merupakan masalah yang sangat kompleks.

Guru sangat menyadari pentingnya motivasi di dalam membimbing. Dalam usaha memotivasi siswa tersebut, tidak ada aturan - aturan yang sederhana. Penyelidikan tentang motivasi, kiranya menjadikan guru peka terhadap kompleksitas masalah ini. Guru hendaknya mengetahui prinsip - prinsip motivasi yang dapat membantu pelaksanaan tugas mengajarnya.

Melihat keadaan tesebut, penulis berusaha dengan kemampuan yang ada untuk mencoba beberapa cara agar pemahaman kosa kata para siswa dapat meningkat, sekaligus dapat menggunakan kosa kata tersebut dalam berbagai makna dan tema. Salah satu teknik pembelajaran yang digunakan penulis untuk meningkatkan vocabulary siswa adalah melalui lagu - lagu dalam bahasa inggris. Dari kerangka berpikir di atas, maka hipotesis tindakan penelitian ini adalah " Apakah menggunakan lagu - lagu bahasa inggris dapat meningkatkan penguasaan kosakata bagi siswa kelas Vlll - 2 SMPN2 Mardingding semester ganjil tahun pelajaran 2015 / 2016 ? 


\section{METODOLOGI PENELITIAN}

\section{A. Setting}

Penelitian tindakan kelas ini dilaksanakan di SMPN 2 Mardingding kelas VIII- 2 pada semester ganjil tahun pelajaran 2015 / 2016. Jumlah siswa kelas VIII - 2 sebanyak 27 siswa, terdiri dari 11 siswa putra dan 16 siswa putri.

Sekolah Menengah Pertama Negeri 2 Mardingding terletak di desa Mardinging kecamatan Mardingding kabupaten Karo Sumatera Utara. Sekolah ini terdiri dari empat belas kelas, yaitu kelas tujuh sebanyak lima kelas, kelas delapan sebanyak lima kelas, dan kelas sembilan sebanyak empat kelas. Keadaan kelas VIIl - 2 pada saat pelajaran cukup kondusif dengan motivasi belajar siswa yang tinggi.

\section{B. Subjek Penelitian}

Subjek penelitian tindakan ini adalah siswa kelas VIIl - 2 SMP N 2 Mardingding. Jumlah siswa kelas VIll - 2 sebanyak 27 siswa.Terdiri dari 11 siswa putra dan 16 siswa putri.

\section{Metode Penelitian}

Dalam penelitian ini, yang digunakan adalah penelitian tindakan kelas. Arikunto ( 2006 ) dalam Suwandi, menjelaskan frasa Penelitian Tindakan Kelas dari unsur kata pembentuknya, yakni penelitian, tindakan, kelas. Penelitian mengacu pada suatu kegiatan mencermati suatu objek dengan menggunakan cara atau aturan metodologi tertentu untuk memperoleh data atau informasi yang bermanfaat untuk meningkatkan mutu suatu hal yang menarik minat dan penting bagi peneliti. Tindakan mengacu pada suatu gerak kegiatan yang sengaja dilakukan dengan tujuan tertentu. Dalam penelitian tindakan kelas, tindakan itu berbentuk rangkaian siklus kegiatan untuk siswa.

Kelas mengacu pada pengertian yang tidak terikat pada ruang kelas, tetapi pada pengertian lebih spesifik. Istilah kelas mengacu pada sekelompok siswa yang dalam waktu sama menerima pelajaran guru yang sama. Kelas bukan wujud ruang, tetapi sekelompok peserta didik yang sedang belajar. Dengan demikian, penelitian tindakan kelas dapat dilakukan tidak hanya di ruang kelas, tetapi di mana saja tempatnya, yang penting ada sekelompok anak belajar. Pembelajaran dapat terjadi di laboratorium, di perpustakaan, di lapangan olahraga, di tempat kunjungan, atau tempat lain.

1. Langkah - langkah Penelitian Tindakan Kelas

Metode penelitian ini adalah penelitian tindakan kelas dengan dua siklus.

1. Siklus 1

a. Perencanaan

Pada tahap ini, penulis mempersiapkan segala instrumen penelitian yang berkenaan dengan tindakan yang akan dilakukan untuk mengatasi masalah pembelajaran yang akan diteliti.

b. Pelaksanaan

Setelah semua perencanaan selesai, tindakan yang akan diberikan kepada siswa diberikan. Pada tahap ini, guru mengajar seperti biasa. Pada saat mengajarkan vocabularies melalui lagu dalam bahasa inggris, penulis memberikan tugas kepada siswa untuk mengartikan kata - kata yang terdapat dalam lagu tersebut. Guru menyuruh siswa untuk menuliskan arti kata - kata yang terdapat dalam lagu itu. 


\section{c. Pengamatan}

Ketka siswa menuliskan arti kata - kata yang terdapat dalam lagu itu, mereka diamati apakah mereka kesulitan dalam menuliskan arti kata - kata yang terdapat dalam lagu itu. Pengamatan meliputi kecepatan serta ketepatan arti kata yang ditulis.

\section{d. Refleksi}

Dari hasil temuan pada tahapan observasing analisa dan dilakukanlah refleksi untuk menentukan langkah selanjutnya.

2. Siklus 2

a. Perencanaan

Pada tahap ini, penulis mempersiapkan segala instrumen penelitian, yang berkenaan dengan tindakan yang akan dilakukan untuk mengatasi masalah pembelajaran yang akan diteliti.

b. Pelaksanaan

Setelah semua perencanaan selesai, tindakan yang akan diberikan kepada siswa diberikan. Pada tahap ini, guru mengajar seperti biasa. Pada saat mengajarkan vocabularies melalui lagu dalam bahasa inggris, penulis memberikan tugas kepada siswa untuk mengartikan kata - kata yang terdapat dalam lagu tersebut kedalam bahasa Indonesia.Guru menyanyikan lagu tersebut satu - satu baris dan diikuti oleh siswa. Guru bersama siswa menyanyikan lagu itu kembali. Guru menyuruh siswa untuk menyanyikan lagu tersebut.Pada siklus kedua ini akan ada perlakukan yang berbeda dari siklus pertama. Siklus kedua ini dilakukan bila siklus pertama indikator kinerja yang diharapkan belum terpenuhi. Dari hasil refleksi akan dirancang tindakan untuk siklus kedua. Jadi apa yang akan akan diilakukan pada tindakan siklus kedua tergantung pada fenomena yang terjadi pada siklus pertama.

c. Pengamatan

Ketika siswa menunjukkan hasil kerja mereka di depan kelas, mereka diamati apakah arti kata - kata yang mereka tulis sudah benar. Pengamatan meliputi kecepatan serta ketepatan dari arti kata yang ditulis.

\section{d. Refleksi}

Dari hasil temuan pada tahapan observasi dianalisis dan dilakukan refleksi untuk mengambil kesimpulan akan dampak perlakuan yang diberikan dan perubahan kinerja yang terjadi pada siklus pertama dan kedua.

\section{Teknik Pengumpulan Data}

a) Pemberian tes tulis dengan menebak arti vocaburies yang terdapat dalam lagu tersebut.

b) Penyebaran kuesioner

c) Pengamatan

d) Wawancara

\section{Teknik Analisa Data}

1. Data yang berupa hasil tes kognitif, dibuat rata - rata dan kesimpulan tentang kecenderungan siswa dalam wawasannya tentang vocabularies dalamlagu yang dinyanyikan. Tes ini dilakukan sebanyak 2 kali, yaitu sebelum tindakan dan sesudah tindakan. Pada awal tindakan dilakukan untuk mengetahui kondisi awal tentang wawasan vocabularies.

2. Hasil kuesioner dianalisis dengan skala likert, yaitu rentang $1-5$ dari hal negatif ke positif. Hasil kuesioner ini semua dibuat rata - rata dan disimpulkan untuk masing - 
masing aspek dalam kuesioner untuk mengetahui keadaan siswa selama melakukan penelitian.

3. Pengamatan dianalisis berdasarkan aspek kecepatan dan ketepatan dalam menuliskan arti kata. Analisisnya berupa rata - rata dari setiap aspek yang kemudian diterjemahkan secara kuantitatif. 


\section{HASIL PENELITIAN DAN PEMBAHASAN}

Kondisi atau keadaan awal sebelum diadakan tindakan menunjukan bahwa sebagian besar para siswa merasa sungkan untuk berkomunikasi dengan menggunakan bahasa Inggris. Hal itu terjadi karena beberapa kemungkinan antara lain sebagai berikut:

1. Siswa kesulitan dalam menangkap materi pembelajaran bahasa Inggris.

2. Siswa merasa malu, sungkan, kurang berani dan sejenisnya atau bahkan takut membuat kesalahan sehingga ditertawai oleh temannya.

3. Kurang bervariasinya teknik pembelajaran bahasa Inggris yang diterapkan oleh guru bahasa Inggrisnya.

4. Kurang adanya kebersamaan/keseragampemahaman dan kerja sama diantara para siswa.

Salah satu solusi untuk meningkatkan kemampuan vocabularies siswa maka peneliti memanfaatkan lagu - lagu sebagai sumber inspirasi belajar yang lebih komunikatif.Penelitian tindakan kelas ini dilaksanakan dalam 2 (dua) siklus, dan masing-masing siklus dilaksanakan 2 (dua) kali pertemuan. Metode ini memanfaatkan lagu sebagai sumber inspirasi belajar.Sebagai penjelasan lebih lanjut, tabel di bawah ini merupakan penggambaran tentang prosedur penelitian tindakan kelas yang telah dilaksanakan oleh peneliti sebagai berikut.

\section{A. Prosedur Penelitian}

\begin{tabular}{|l|l|l|}
\hline Pra Peneltiain & Kegaitan & Deskripsi \\
\hline & Wawancara & $\begin{array}{l}\text { Mengetahui masalah } \\
\text { dalam pembelajaran. }\end{array}$ \\
\hline & Observasi & $\begin{array}{l}\text { Mengetahui masalah } \\
\text { dalam pembelajaran } \\
\text { selama proses } \\
\text { pembelajaran dan } \\
\text { pengajaran. }\end{array}$ \\
\hline & Pre Test & $\begin{array}{l}\text { Mengetahui tingkat } \\
\text { kemampuan berbicara } \\
\text { bahasa Inggris. }\end{array}$ \\
\hline
\end{tabular}

\section{B. Solusi Tindakan}

Peneliti menterjemahkan lagu - lagu bahasa Indonesia yang diketahui dan disukai siswa ke dalam bahasa inggris dan menyanyikan lagu tersebut dan diikuti oleh siswa. Peneliti juga akan meminta siswa menyanyikan lagu tersebut secara bersama - sama.

\begin{tabular}{|l|ll|l|}
\hline $\begin{array}{l}1 . \quad \text { Pelaksanaan } \\
\text { Tindakan }\end{array}$ & \multicolumn{2}{|c|}{} \\
\hline 2. Siklus I & \multicolumn{1}{|c|}{ Tahap } & Keterangan \\
\cline { 2 - 4 } & 1. & Perencanaan & $\begin{array}{l}\text { Merencanakan } \\
\text { tindakan kelas untuk } \\
\text { siklus I. }\end{array}$ \\
\cline { 2 - 4 } & 2. & Tindakan & $\begin{array}{l}\text { Melaksanakan } \\
\text { tindakan melalui dua }\end{array}$ \\
\hline
\end{tabular}




\begin{tabular}{|c|c|c|}
\hline & \multirow[b]{2}{*}{ 3. Pengamatan } & \multirow{2}{*}{\begin{tabular}{lr}
\multicolumn{2}{l}{ kali pertemuan. } \\
Mengamati & proses \\
pembelajaran & dan \\
pengajaran. &
\end{tabular}} \\
\hline & & \\
\hline & 4. Refleksi & $\begin{array}{l}\text { Merefleksi hasil proses } \\
\text { pembelajaran. }\end{array}$ \\
\hline & 5. Revisi & $\begin{array}{lr}\text { Merevisi } & \text { perencanaan } \\
\text { untuk } & \text { siklus } \\
\text { berikutnya. } & \end{array}$ \\
\hline \multirow[t]{5}{*}{ Siklus II } & 1. Perencanaan & $\begin{array}{l}\text { Merencanakan } \\
\text { tindakan unutk siklus } \\
\text { ke II. }\end{array}$ \\
\hline & E. Tindakan & $\begin{array}{l}\text { Melaksanakan } \\
\text { tindakan melalui dua } \\
\text { kali pertemuan. }\end{array}$ \\
\hline & F. Pengamatan & $\begin{array}{lr}\text { Mengamati } & \text { proses } \\
\text { pembelajaran } & \text { dan } \\
\text { pengajaran. } & \end{array}$ \\
\hline & G. Refleksi & $\begin{array}{l}\text { Merefleksikan hasil } \\
\text { proses pembelajaran. }\end{array}$ \\
\hline & H. Revisi & $\begin{array}{lr}\text { Merevisi } & \text { perencanaan } \\
\text { untuk } & \text { siklus } \\
\text { berikutnya. } & \end{array}$ \\
\hline
\end{tabular}

\section{Pra-Penelitian}

Tahap pra-penelitian diselenggarakan untuk mengetahui permasalahan yang terjadi dalam proses pembelajaran dan pengajaran. Adapun kegiatan pra-penelitian mencakup antara lain: 1) mengamati pembelajaran dan pengajaran, 2) memberikan pre-test untuk mengetahui tingkat kemampuan siswa.

Pada awalnya, sebelum pelaksanaan penelitian, pembelajaran untuk kelas 8 dilakukan secara konvensional yang dilakukan di ruang kelas.Pembelajaran lebih banyak didominasi oleh guru. Hanya sesekali guru memberikan pertanyaan yang berkaitan dengan materi kepada beberapa siswa, sehingga tidak seluruh siswa mendapat kesempatan merespon/menanggapi pertanyaan yang diberikan oleh gurunya. Berdasarkan pengalaman sebelumnya mengenai model pembelajaran yang terbukti membawa dampak positif maupun negatif, maka peneliti mempertimbangkan beberapa alternatif untuk pemecahan masalah pembelajaran.

Setidak-tidaknya ada agenda utama dalam penelitian tindakan kelas ini yaitu untuk memecahkan permasalahan siswa yang berhubungan dengan kurangnya motivasi belajar dan kurang / rendahnya vocabularies siswa. Ada beberapa indikator yang menyatakan bahwa para siswa memiliki vocabularies yang masih kurang/rendah: 1) mereka kurang memperhatikan pelajaran yang disampaikan oleh guru, 2) mereka merasa enggan mengungkapkan pikiran/gagasan dengan bahasa inggris karena takut salah, 3) mereka sering membahas permasalahan yang tidak ada kaitannya dengan pelajaran, 4) mereka juga merasa enggan menggunakan bahasa Inggrisnya karena sungkan.

Untuk mengetahui lebih jauh penguasaan vocabularies siswa, peneliti menggunakan angket yang harus diisi oleh siswa sebelum maupun sesudah dilaksanakan 
penelitian tindakan kelas. Berdasarkan hasil dari angket yang telah dikerjakan para siswa, terbukti bahwa mereka benar-benar memiliki vocabularies yang rendah. Data kualitatif dari angket motivasi belajar siswa diubah menjadi data kuantitatif melalui skala Likert. Nilai rata - rata kemampuan vocabularies siswa menunjukkan angka 30

\section{Pelaksanaan Penelitian}

Pelaksanaan penelitian dilakukan didalam kelas untuk meningkatkan vocabularies melalui Penelitian Tindakan Kelas (PTK). Penelitian ini dilaksanakan melalui proses putaran atau siklus. Tiap-tiap putaran atau siklus dalam pembelajaran terdiri dari empat langkah yaitu: 1) perencanaan tindakan, 2) pelaksanaan tindakan, 3) pengamatan (observasi) tindakan, dan 4) refleksi dari hasil-hasil pengamatan.

1. Siklus I

1. Perencanaan (Planning)

2. Pelaksanaan (Action)

3. Pengamatan (Observing)

4. Refleksi (Reflection)

5. Revisi (Revision)

\section{Perencanaan}

Dalam tingkatan ini, pertama-tama penulis membuat perencanaan tentang jenis tindakan apa yang akan dilakukan dan mempersiapkan segala sesuatunya yang berkaitan dengan kebutuhan tindakan kelas seperti misalnya, membuat rencana pengajaran, menyiapkan lembar pengamatan untuk mencatat kegiatan siswa, menyiapkan alat-alat bantu pengajaran dan sebuah instrument test, dan sebagainya.

Kemudian, peneliti mengidentifikasi masalah yang mengacu terhadap proses belajar-mengajar yang akan diteliti dalam penelitian ini. Dalam hal ini, tentu saja masalah-masalah yang berkaitan dengan kemampuan vocabularies siswa dalam mempelajari bahasa Inggris apakah mereka benar-benar memiliki kesulitan dalam menguasainya.

Setelah itu, peneliti menyiapkan bahan-bahan yang akan diajarkan ke dalam kelas. Dalam penelitian ini, dia akan mengambil tiga tingkatan (cycle) jika ternyata pada tataran tingkat satu dan dua belum cukup signifikan untuk mendapatkan kejelasan hasil yang sesungguhnya. Pada akhir setiap tingkatan, peneliti akan menganalisa dan mengevaluasinya untuk mendapatkan perbaikan sampai diperoleh solusi masalah terbaik.

\section{Pelaksanaan Tindakan (Implementasi)}

Peneliti melakukan rencana pelajaran di dalam kelas. Dia melakukan langkah demi langkah kegiatan belajar-mengajar berdasarkan rencana pelajaran yang telah disiapkan sebelumnya. Dalam hal ini, dia mengimplementasikan pengajaran denganmenggunakan lagu - lagu dalam bahasa Inggris.Siklus I dilaksanakan ke dalam dua kali pertemuan. Masing-masing pertemuan terdiri dari: (warming up), presentasi (presentation), latihan (practice), dan produksi (production). Berikut adalah langkahlangkah secara detail yang dilakukan sebagai berikut;

1) Pertemuan Pertama 
(a) Kegiatan awal (warming up)

Peneliti melaksanakan kegiatan pembelajaran pada hari Senin, 14 September 2015 jam ke 4- 5. Terlihat siswa sedang mempersiapkan diri untuk mengikuti pelajaran berikutnya yaitu bahasa Inggris. Siswa-siswi sedang mempersiapkan alat tulis dan buku mereka.

Ketika guru (peneliti) masuk ruangan, sebagian besar dari merekatelah nampak rapi dan siap mengikuti pelajaran. Guru menyapa mereka dan berbicara sebentar dengan para siswa sembari menunggu mereka menata / mempersiapkan diri mereka. Setelah semuanya lengkap dan siap di kelas selanjutnya guru mengucapkan salam kepada mereka dengan bahasa Inggris sebagaimana yang selalu dilakukannya pada setiap mengawali pelajaran. Para siswa masih nampak bersemangat merespon salam yang diberikan guru dengan penuh senyum ramah dan menyenangkan.

Kemudian guru melanjutkan tugas mengajarnya yaitu menjelaskan apa yang akan dipelajari. Dia menjelaskan bahwa para siswa akan mempelajari vocabularies melalui lagu bahasa inggris yang telah dia siapkan. Namun sebelumnya sebagai brain storming guru menanyakan tentang lagu - lagu bahasa inggris yang siswa ketahui. Berikut adalah petikan brain storming yang dilakukan oleh guru; "Well, students. Now we're learning about vocabularies from the song, the title of the song is forget. Do you know this song?" guru bertanya. "No, Mom. like if we sing this song ? guru bertanya kembali. "yes, mom." Kemudian guru menuliskan lagu di papan tulis dan menyuruh siswa mencatat lagu itu di buku mereka. Setelah siswa selesai mencatat lagu itu guru menyuruh mereka membaca kata - kata yang terdapat dalam lagu itu secara bersama sama. Pengamatan dilakukan apakah mereka dapat melafalkan kata - kata dalam lagu itu dengan benar.

Sebelum guru melanjutkan pembahasan tentang topik yang akan dipelajari yang berkaitan dengan lagu itu, Dia menyuruh beberapa siswa untuk membaca dan menyebutkan arti kata- kata yang terdapat dalam lagu itu. Sementara guru mencatat nama siswa yang membaca dan mengucapakan arti kata yang terdapat dalam lagu itu dengan benar sambil memberi penguatan / pujian kepada siswa yang membaca dan mengucapkan arti kata dalam lagu itu misalnya ; good, all right, okay, excellent, dan lain sebagainya. Kemudian guru menyuruh siswa untuk mengambil selembar kertas dan menuliskan namanya di kertas itu dan mencatat semua kata - kata yang terdapat dalam lagu itu dan menuliskan artinya dalam bahasa Indonesia.

Latihan (Practice)

Dalam tingkatan ini, guru menjelaskan cara mencatat dan menuliskan arti kata dalam lagu tersebut dan menerangkan manfaat materi yang akan dipelajarinya melalui lagu itu. Setelah semuanya jelas, mulailah siswa melaksanakan tugas yang diberikan guru. Pada saat yang sama, guru (peneliti) dan juga sebagai (observer/pengamat) mengamati seluruh proses kegiatan yang berjalan dikelas dengan sesekali mendatangi siswa dan menanyakan apakah ada kesulitan yang ditemukan atau tidak. Jika ada guru berusaha membantu kesulitan yang dihadapi, tetapi jika tidak dia memujinya sambil memberi penguatan semangat belajar.

Penyelesaian tugas yang diberikan berlangsung kurang lebih 40 menit, kemudian setiap siswa diminta mengumpulkan hasil kerjanyakepada guru. Hasil kerja siswa itu diperiksa oleh guru sebagai peneliti.

3. Pengamatan Tindakan 
Dalam tingkatan ini, guru sebagai pengamat bertugas mengamati cara kerja siswa dalam menuliskan arti kata - kata dalam lagu itu. Untuk guru sesekali mendatangi siswa untuk menanyakan apakah ada kesulitan atau tidak. Jika ternyata ada kesulitan maka guru wajib membantu sekaligus memberi penguatan terhadap kegiatan itu.Tetapi jika memang tidak ada kesulitan maka guru cukup memberi penguatan dan pujian sebagai bentuk motivasi mereka agar lebih bersemangat.

Untuk pertemuan pertama, para siswa nampak bersemangat mengerjakan tugas yang diberikan oleh guru.Menurut pengamatan dia para siswa berkonsentrasi penuh dalam mengerjakan tugas itu.Masing-masing mengerjakannya sesuai dengan pengetahuan mereka. Tetapi, memang ada beberapa siswa yang masih belum aktif berpartisipasi. Tetapi paling tidak mereka sudah terlibat dalam mengerjakan tugas yang diberikan. Pada tahap ini, rata - rata hasil yang ditunjukkan siswa belum bagus. Artinya kemampuan menuliskan kata - kata masih kurang, masih ada beberapa siswa yang kurang teliti dalam menuliskan kata - kata sehingga penulisannya masih salah. Beberapa siswa lainnya juga kesulitan dalam menuliskan arti kata - kata dalam lagu itu.

Dalam tingkatan ini, siswa diminta membacakan kata - kata yang terdapat dalam lagu itu. Pertama guru menawarkan kepada siswa yang tanpa ditunjuk mau mengawali membacakannya. Satu siswa yang bernama Ica mengangkat tangan dan siap membacakannya. Untuk itulah guru mengajak siswa lainya memberi semangat bersama dengan bertepuk tangan. Ica membaca kata demi kata dengan tidak lancar dan kurang tepat,dan dilanjutkan siswa lain untuk membacakannya tetapi tidak lancar dan tidak benar juga. Kemudian guru membacakan kata - kata yang terdapat dalam lagu itu satu persatu dan diikuti oleh siswa. Setelah beberapa kali dibacakan dan diucapkan secara bersama - sama kegiatan belajar sudah saatnya berakhir.

\section{E. Refleksi}

Pada akhir kegiatan pertama, diinformasikan bahwa sebagai tindak lanjut kegiatan tadi siswa disuruh mengulang kata - kata yang sudah dibacakan di rumah dan akan dinyanyikan di pembelajaran berikutnya.

Sebelum mengakhiri kegiatan, peneliti menanyakan apakah ada pertanyaan atau tidak. Karena nampaknya tidak ada dan semuanya sudah jelas maka peneliti segera mengakhiri kegiatan dengan mengucapkan terimakasih dan salam perpisahan.

\section{2). Pertemuan kedua}

\section{(a). Pemanasan dan presentasi}

Pada pertemuan kedua kegiatan pembelajaran dilaksanakan pada hari

Kamis, 17 September 2015 jam ke 6 - 7. Terlihat siswa sedang mempersiapkan diri untuk mengikuti pelajaran berikutnya yaitu bahasa Inggris. Siswa-siswi sedang mempersiapkan alat tulis dan buku mereka.

Ketika guru (peneliti) masuk ruangan, sebagian besar dari mereka telah nampak rapi dan siap mengikuti pelajaran. Guru berbicara sebentar dengan para siswa sembari menunggu mereka menata/merapikan diri mereka. Setelah semuanya lengkap dan siapselanjutnya guru mengucapkan salam kepada mereka dengan bahasa Inggris sebagaimana yang selalu dilakukannya pada setiap mengawali pelajaran. Para siswa masih nampak bersemangat merespon salam yang diberikan guru dengan penuh senyum ramah dan menyenangkan. 
Telah diumumkan sebelumnya bahwa kegiatan pembelajaran hari ini adalah melanjutkan materi sebelumnya yaitu para siswa menyanyikan lagu yang telah dipersiapkan guru di pertemuan sebelumnya.

Setelah saling memberikan salam antara peneliti dan siswa, kemudian peneliti menjelaskan kegiatan pada hari ini yaitu menyanyikan lagu yang sebelumnya dituliskan dan dicari arti kata - katanya.

\section{(1) Latihan (Practice)}

Peneliti memulai kegiatannya yaitu meminta siswa membacakan kata - kata yang terdapat dalam lagu bahasa inggris yang di buat sebelumnya. Kemudian setelah selesai membacakan kata - kata yang terdapat dalam lagu itu, peneliti mulai menyanyikan lagu tersebut baris demi baris dan diikuti oleh siswa. Setelah itu siswa bersama peneiti menyanyikan lagu tersebut secara bersama - sama dan diulang beberapa kali sampai siswa mahir dan lancar mengucapkan dan melafalkan kata - kata yang terdapat dalam lagu itu. Setelah siswa lancar menyanyikan lagu tersebut peneliti hanya menyuruh siswa menyanyikani lagu itu kembali tanpa diikuti oleh peneliti.Setelah siswa betul - betul lancar dalam menyanyikan lagu itu, peneliti menyuruh siswa menterjemahkan lagu itu ke dalam bahasa Indonesia dan dibantu oleh peneliti untuk menyempurnakan terjemahan tersebut.Kegiatan ini berlangsung selama waktu 30 menit. Berikutnya penelitimenyuruh siswa menyanyikan lagu tersebut dalam bahasa Indonesia secara berulang - ulang sampai siswa lancar menyanyikannya. Kemudian peneliti menanyakan kembali arti kata - kata yang terdapat lagu tersebut tanpa melihat buku, rata - rata siswa dengan mudah mengingat arti kata - kata yang terdapat dalam lagu itu.

10 (sepuluh) menit menjelang akhir kegiatan peneliti memberikan angket tanggapan siswa terhadap proses pembelajaran yang dilakukan oleh peneliti selama 2 (dua) kali pertemuan untuk diisi sesuai dengan apa yang telah dirasakan / diikuti selama kegiatan tersebut. Untuk menghindari kekawatiran siswa terhadap pengisian data maka siswa tidak perlu mencantumkan nama. Sehingga para siswa bebas memberikan pendapatnya secara objektif.

Setelah semuanya selesai mengisi angket, kemudian peneliti minta mengumpulkanya dan mengingatkan bahwa pada pertemuan yang akan datang kita masih akan membicarakan topic yang sama yaitu menyanyikan lagu dalam bahasa inggris. Diharapkan siswa supaya mempersiapkan diri dengan menghapal lagu yang sudah dipelajari dan mampu menyanyikannya tanpa melihat teks lagu. Akhirnya peneliti mengakhiri kegiatanya dengan mengucapkan terimakasih dan salam perpisahan.

1) Pengamatan (Observation)

Peneliti dan sebagai pengamat (observer) mencatat kejadian-kejadian penting selama proses kegiatan belajar- mengajar berlangsung setelah pelajaran usai pada 2 (dua) kali pertemuan siklus pertama. Dia juga mencatat kelemahan dan kelebihan daripada implementasi pelajaran yang menggunakan lagu sebagai cara untuk meningkatkan dan mendorong kemampuan siswa dalam meningkatkan vocabularies siswa.

Dalam kaitannya kegiatan tersebut di atas peneliti sudah menyediakan lembaranlembaran observasi untuk memudahkan pengamatan kegiatan siswa selama pembelajaran berlangsung. Hasil pengamatan akan dijadikan bahan refleksi demi tercapainya kemajuan pembelajaran. Secara umum proses kegiatan pembelajaran berbicara dengan menggunakan lagu berjalan lancar, meskipun terjadi keramaian 
sebagai akibat dari penerapan metode tersebut tetapi pada prinsipnya justru dengan demikian anak lebih mudah melafalkan dan mengingat kata-kata bahasa inggris yang terdapat dalam lagu tersebut. Sebab menurut pengamatan peneliti semua siswa nampak memperhatikan dengan seksama materi pembelajaran vocabularies, sehingga suasana kelas nampak semakin hidup dan menyenangkan.

Namun demikian hasil kegiatan pembelajaran pada siklus pertama belum memuaskan, karena masih ada beberapa kelemahan/kekurangan yang perlu diperbaiki sehingga pencapaian hasil kegiatan berbicara bisa lebih maksimal.

2) Refleksi (Reflecting)

Setelah melakukan kegiatan belajar mengajar yang menggunakan lagu, dia mencatat kejadian-kejadian didalam kelas sebagai efek/pengaruh terhadap tindakan yang telah dilakukan. Dia mengevaluasi proses dan hasil implementasi penggunaan lagu dalam pengajaran. Keuntungan/manfaat evaluasi untuk memutuskan apa yang seharusnya dilakukan untuk tingkatan (cycle) berikutnya.

Berdasarkan hasil observasi yang dikumpulkan dalam catatan lapangan (field note) pengamat dan peneliti merefleksikan beberapa temuan positif sebagai kelebihan atau keuntungan dari penggunaan lagu dalam bahasa inggris dan negatif sebagai kelemahannya pada siklus pertama. Adapun penemuan-penemuan tersebut adalah sebagai berikut:

a) Sisi positif (keuntungan)

1) Kegiatan pembelajaran melalui lagu - lagu yang dinyanyikan, mengundang minat belajar siswa untuk bersungguh-sungguh.

2) Suasana kelas nampak lebih hidup walaupun mungkin menimbulkan keramaian tetapi bermakna.

3) Meningkatkan hubungan sosial mereka agar semakin kuat.

4) Mendorong keberanian mereka untuk bertanya menggunakan bahasa Inggris.

5) Terjadi peningkatan vocabularies siswa dalam proses pembelajaran.

6) Terjadi peningkatan kemampuan bicara berbahasa Inggris, terbukti ada peningkatan rata - rata nilai siswa pada post-test dalam siklus I.

b) Sisi negatif (kelemahan)

1) Suasana kelas jadi ramai karena tahap awal menyanyikan lagu bahasa Inggris asing bagi mereka sehingga ada beberapa siswa hanya tertawa tanpa bernyanyi.

2) Ada beberapa siswa yang masih pasif.

3) Ada beberapa siswa yang pada awal kegiatan nampak antusias, tetapi pada akhir kegiatan terlihat jenuh.

4) Dialek daerah setempat masih mendominasi logat mereka dalam bernyanyi lagu bahasa Inggris.

5) Ada beberapa siswa yang ketika bernyanyi suaranya tidak keras atau lemah, sehingga tidak begitu jelas.

\section{Revisi Perencanaan}

Untuk memecahkan permasalahan yang muncul pada siklus I, peneliti merevisi perencanaan untuk tindakan berikutnya, sehingga kelemahan dan kekurangan yang ditemukan pada siklus I dapat dikurangi atau bahkan kalau bisa diilangkan sedikit demi sedikit. Upaya peningkatan motivasi belajar dan kemampuan berbicara bahasa Inggris untuk siklus II melalui kegiatan pembelajaran melalui lagu-lagu bahasa Inggris pada 
prinsipnya mempertahankan kelebihan-kelebihan yang sudah berjalan dengan baik. Adapun berbagai kelemahan yang muncul pada siklus I sebagaimana tersebut di atas, peneliti mengupayakan solusi sesuai dengan kelemahan dan kekurangan yang ada secara optimal.

\section{Siklus II}

\section{1) Persiapan Tindakan}

Tindakan perencanaan untuk siklus II didasarkan pada kelemahan-kelemahan atau kekurangan-kekurangan yang ditemukan pada siklus I. Dalam siklus II ini, kegiatan pembelajaran berbicara dengan menggunakan metode IBT (Inquiry Based Teaching) masih dilanjutkan dalam upaya peningkatan motivasi belajar dan kemampuan bicara berbahasa Inggris. Untuk mengatasi masalah-masalah tersebut pada siklus I, peneliti merevisi perencanaan sebagai berikut:

\begin{tabular}{|l|l|l|}
\hline No. & \multicolumn{1}{|c|}{ Masalah } & \multicolumn{1}{c|}{ Solusi } \\
\hline 1 & Suasana kelas jadi ramai. & $\begin{array}{l}\text { Diarahkan agar keramaianya } \\
\text { terkendali dan } \\
\text { bermakna. }\end{array}$ \\
\hline 2 & $\begin{array}{l}\text { Ada beberapa siswa yang } \\
\text { masih pasif. }\end{array}$ & $\begin{array}{l}\text { Diberi stimulan agar } \\
\text { lebih aktif berpartisipasi. }\end{array}$ \\
\hline 3 & $\begin{array}{l}\text { Ada beberapa siswa yang pada } \\
\text { awal kegiatan nampak antusias, } \\
\text { tetapi pada akhir kegiatan } \\
\text { terlihat jenuh. }\end{array}$ & $\begin{array}{l}\text { Diberi semangat agar tetap } \\
\text { mampu menjaga } \\
\text { keseriusanya } \\
\text { dan agar tidak jenuh siswa } \\
\text { diajak menyanyi. }\end{array}$ \\
\hline 4 & $\begin{array}{l}\text { Dialek daerah setempat masih } \\
\text { mendominasi logat mereka } \\
\text { dalam bernyanyi lagu bahasa } \\
\text { Inggiris. }\end{array}$ & $\begin{array}{l}\text { Diarahkan supaya lebih banyak } \\
\text { berlatih dan mengikuti dialek } \\
\text { dan logat bahasa inggris. }\end{array}$ \\
\hline 5 & $\begin{array}{l}\text { Ada beberapa siswa yang } \\
\text { ketika bernyanyi suaranya } \\
\text { tidak keras atau lemah, } \\
\text { sehingga tidak begitu jelas. }\end{array}$ & $\begin{array}{l}\text { Diingatkan agar siswa } \\
\text { bernyanyi } \\
\text { dengan kuat jelas dan } \\
\text { dingatkan } \\
\text { agar tidak takut salah. }\end{array}$ \\
\hline
\end{tabular}

\section{2) Implementasi Tindakan}

Tindakan yang dilakukan dalam siklus II ini, peneliti meminta para siswa mempersiapkan diri untuk menyanyikan lagu yang sudah dipersiapkan sebelumnya. Sebagaimana informasi sebelumnya bahwa para siswa supaya mempersiapkan diri untuk menyanyikan lagu itu tanpa melihat teks, agar lebih memudahkan mereka dalam mengingat arti kata-kata dalam lagu itu dan dapat melapalkan dan mengucapkannya dengan benar dan lebih lancar. Implementasi tindakan dalam siklus ini dilakukan ke dalam 2 (dua) kali pertemuan. Setiap pertemuan dibagi menjadi empat bagian yaitu pemanasan (warming up), penyajian (presentation), latihan (practice), dan produksi (production). 


\section{a) Pertemuan Pertama}

(1) Pemanasan (warming up) dan Penyajian (Presentation)

Peneliti melaksanakan kegiatan pembelajaran pada hari Senin, 21 September 2015 pada jam ke 4 - 5. Terlihat siswa sedang mempersiapkan diri untuk mengikuti pelajaran berikutnya yaitu bahasa Inggris. Siswa-siswi sedang mempersiapkan alat tulis dan buku mereka.

Ketika guru (peneliti) memasuki ruangan, sebagian besar dari mereka telah nampak rapi dan siap mengikuti pelajaran. Guru berbicara sebentar dengan para siswa sembari menunggu mereka menata/merapikan diri mereka. Setelah semuanya lengkap dan siap selanjutnya guru menyapa mereka dengan bahasa Inggris sebagaimana yang selalu dilakukannya pada setiap mengawali pelajaran. Para siswa masih nampak bersemangat merespon salam yang diberikan guru dengan penuh senyum ramah dan menyenangkan.

Selanjutnya peneliti menanyakan apakah para siswa telah mempersiapkan diri menyanyikan lagu yang dibuat sebelumnya tanpa teks. Ternyata siswa memang telah mempersiapkan diri mereka sebagaimana dipesankan oleh peneliti sebelumnya yaitu siswa menghapal lagu tersebut di rumah.

\section{Latihan (Practice)}

Kegiatan pembelajaran berlanjut, para siswa mempersiapkan diri dengan penuh semangat menyanyikan lagu tersebut. Peneliti memberi aba-aba agar siswa menyanyikan lagu tersebut tanpa teks. Dalam kegiatan kali ini, peneliti lebih pro-aktif menstimulus mereka agar mereka lebih optimal bernyanyi sebagai upaya untuk mengatasi kelemahan dan kekurangan yang ditemukan pada siklus I. Para siswa menyanyikan lagu itu dengan semangat tapi belum begitu lancar. Peneliti menyuruh siswa mengulang lagi supaya pengucapan lebih lancar dan lebih jelas. Setelah dinyanyikan bersama-sama dan diulang beberapa kali siswa sudah lancar menyanyikan lagu tersebut tanpa teks.

\section{(3) Production}

Dalam tahapan ini, para siswa diminta untuk mengambil secarik kertas dan menuliskan nama masing-masing siswa di kertas itu. Kemudian peneliti menyuruh siswa menuliskan kosa kata yang terdapat dalam lagu tersebut juga menuliskan artinya dalam bahasa Indonesia. Ternyata para siswa lebih berkonsentrasi dibandingkan sebelumnya, dan mampu menuliskan kosa kata dengan teliti, lancar dan benar. Mereka menyelesaikan tugas yang diberikan selama 15 menit. Kemudian peneliti menyuruh siswa mengumpulkan hasil kerja mereka untuk diperiksa.

b) Pertemuan Kedua

(1) Pemanasan (warming up) dan Presentasi (Presentation)

Peneliti melaksanakan kegiatan pembelajaran pada hari Kamis, 24 September 2015 jam ke 6 - 7. Terlihat siswa sedang mempersiapkan diri untuk mengikuti pelajaran berikutnya yaitu bahasa Inggris. Siswa-siswi sedang mempersiapkan alat tulis dan buku mereka.

Ketika guru (peneliti) masuk ruangan, sebagian besar dari mereka telah nampak rapi dan siap mengikuti pelajaran. Guru berbicara sebentar dengan para siswa sembari menunggu mereka menata/merapikan diri mereka. Setelah semuanya lengkap dan siap dikelas selanjutnya guru menyapa mereka dengan bahasa Inggris sebagaimana yang 
selalu dilakukannya pada setiap mengawali pelajaran. Para siswa masih nampak bersemangat merespon salam yang diberikan guru dengan penuh senyum ramah dan menyenangkan.

Setelah mengucapkan salam dan mengecek kehadiran mereka, peneliti segera menjelaskan kegiatan apa yang akan dilakukan pada hari ini. Adapun kegiatan pada hari ini adalah menyanyikan lagu baru yang lebih sulit dan lebih panjang dari lagu sebelumnya yang sudah disiapkan peneliti.

Sebagaimana kegiatan sebelumnya peneliti menuliskan lagu baru di papan tulis dan menyuruh siswa mencatat lagu tersebut di bukunya sambil diamati apakah siswa sudah lebih lancar dan lebih teliti dalam menuliskan kosa kata yang terdapat dalam lagu tersebut. Setelah siswa selesai menuliskan lagu baru tersebut sebagaimana yang dilakukan peneliti sebelumnya, peneliti membacakan kosa-kata yang terdapat dalam lagu itu dan menyebutkan artinya dalam bahasa Indonesia dan diikuti oleh siswa. Pada kegiatan kali ini terlihat para siswa lebih bersemangat dan antusias dalam mengucapkan kata-kata yang terdapat dalam lagu baru tersebut. Peneliti melihat siswa jauh lebih lancar dalam mengucapkan dan melapalkan kata-kata dalam lagu tersebut terutama melafalkan kata-kata yang sama atau yang terdapat pada lagu sebelumnya. Kemudian peneliti menyanyikan lagu baru tersebut dan diikuti oleh siswa. Selanjutnya peneliti menyuruh siswa secara bersama-sama menyanyikan lagu tersebut tanpa diikuti peneliti. Setelah beberapa kali menyanyikan lagu tersebut peneliti menyuruh siswa menyanyikannya kembali tanpa melihat teks. Dan siswa terlihat merasa jauh lebih mudah mengingat lagu tersebut dibandingkan dengan lagu yang pertama dinyanyikan. Setelah siswa lancar menyanyikan lagu baru dalam bahasa inggris tersebut peneliti menyuruh siswa menyanyikan kembali dalam bahasa Indonesia. Di sini terlihat hampir semua arti kosa dalam lagu tersebut diingat oleh siswa atau dengan kata lain hanya beberapa kata-kata sulit yang tidak diingat oleh siswa.

Tetapi di sini terlihat siswa lebih bersemangat dan berusaha mengingat beberapa kata - kata sulit yang sulit diingat tadi dengan mengucapkannya secara berulang-ulang. Siswa juga sudah mulai mencoba berkomunikasi dalam bahasa iinggris terutama menggunakan kata-kata yang terdapat dalam lagu sebelumnya dan dalam lagu yang baru dipelajari. Dengan cara memberikan pertanyaan kepada temannya dan guru menggunakan bahasa Inggris, atau bahkan obrolan-obrolan kecil yang samar-samar peneliti dengar walaupun masih juga tercampur dengan bahasa ibu mereka tetapi sudah lebih banyak dan lebih sering menggunakan bahasa Inggris. Peneliti sendiri selalu menggunakan bahasa Inggris ketika mengajar. Mengerti atau tidak, yang penting anak membiasakan selalu mendengar suara-suara bahasa Inggris. Itu dilakukan karena diharapkan para siswa mendapat pembiasaan menggunakan bahasa Inggris setiap hari.

Tahap akhir menjelang penutupan kegiatan peneliti memberikan test lisan dengan 5 (lima) pertanyaan berdasarkan apa yang telah disajikan ternyata setiap anak dapat merespon/menjawab pertanyaan yang diberikan oleh peneliti (guru). Dan pada akhirnya kegiatan pembelajaran segera diakhiri . Sebelum pelajaran diganti, peneliti menyebarkan angket tanggapan siswa terhadap kegiatan proses pembelajaran yang telah mereka ikuti selama 2 (dua) kali pertemuan kepada siswa. Sebagaimana sebelumnya siswa tidak perlu mencantumkan nama (identitasnya) agar lebih objektif.

Setelah selesai, peneliti mengumpulkan angket tersebut dan selanjutnya segera mengakhiri kegiatan pembelajaran dengan mengucapkan terimakasih dan salam 
perpisahan. Terakhir mereka memberikan applause bersama sebelum peneliti keluar kelas.

\section{3) Pengamatan Tindakan}

Semua kegiatan pembelajaran peningkatan motivasi dan kemampuan berbicara tidak luput dari pengamatan observer, dia menulis hasil pengamatan di atas lembar pengamatan (field notes) yang sudah disiapkan oleh peneliti untuk dijadikan bahan masukan demi perbaikan proses pembelajaran dan pengajaran. Secara umum proses pembelajaran dan pengajaran berjalan lancar sesuai yang diharapkan. Kondisi positif yang diciptakan para siswa nampaknya dipengaruhui oleh materi yang menjadikan siswa benar-benar memperhatikan materi pembelajaran, karena mereka beranggapan bahwa pembelajaran ini menantang secara emosional, intelektual dan fisikal. Semangat siswa untuk belajar terlihat bahwa mereka sekarang semakin lebih percaya diri.

Hampir semua siswa bisa menikmati kegiatan pembelajaran berbicara bahasa Inggris melalui penggunaan lagu - lagu dalam bahasa Inggris. Hasil pembelajaran pada sklus II ini terlihat nampak memuaskan, terlihat hanya sedikit kelemahan-kelemahan dan kekurangan-kekurangan. Contohnya dengan menyanyikan lagu - lagu dalam bahasa Inggris para siswa cenderung ramai tetapi memang itu merupakan efek (akibat) dari penerapan metode tersebut.

Secara umum terjadi peningkatan yang sangat berarti dalam vocabularies, ini terjadi karena mereka merasa lebih yakin akan lebih mudah mempelajari dan mengingat kata-kata dalam bahasa Inggris melalui penggunan lagu-lagu dan mereka sadar tuntutan yang mau tidak mau harus mereka kuasai sehingga pada saat-saat bernyanyi seperti itu mereka bisa melatih dan membiasakan diri dengan bahasa inggris dan merasa termotivasi untuk mau belajar atas kesadaran sendiri.

4) Refleksi Hasil dari Pengamatan Tindakan

Berdasarkan hasil observasi yang terkumpul, penagamat dan peneliti mengumpulkan data-data sebagai berikut:

a) Sisi Positif

1) Dengan menggunakan lagu-lagu bahasa Inggris dalam pembelajaran berbicara Bahasa Inggris sangat menarik dan memacu perhatian siswa. Terbukti mereka terlihat lebih pro-aktif, tidak terkekang (bebas), rileks tetapi serius dalam belajar.

2) Terjadi peningkatan vocabularies siswa selama proses pembelajaran berlangsung. Terbukti mereka lebih rajin dan antusias dalam mengikuti pembelajaran maupun menggunakan bahasa Inggris.

3) Terjadi peningkatan vocabularies siswa, terbukti dari hasil tes berbicara untuk post-test di akhir siklus II menunjukan hasil yang lebih baik dari sebelumnya.

b) Sisi Negatif

1) Keramaian pasti muncul sebagai akibat dari bernyanyi bersama.

2) Bagi siswa lamban dan atau siswa yang malu merupakan tantangan untuk lebih berpacu diri karena mau tidak mau mereka harus ikut bernyanyi bersama - sama.

5). Pengamatan Refleksi

1. Siklus Tindakan I 
Siklus tindakan I ini meliputi perencanaan, tindakan observasi dan refleksi. Tahap perencanaan yaitu: guru merancang skenario pembelajaran dengan menggunakan lagu lagu dalam bahasa Inggris, tahap-tahapanya adalah sebagai berikut:

a) Guru menyampaikan tujuan dan memberikan motivasi tentang pentingnya vocabularies dalam bahasa Inggris. Bahasa Inggris merupakan alat komunikasi penting yang harus dikuasai siswa secara komunikatif.

b) Guru menjelaskan tentang cara-cara peningkatan vocabularies melalui lagu-lagu dalam bahasa Inggris.

c) Guru memberi tugas individu dimana para siswa diberi tugas supaya melakukan pengamatan, pengidentifikasian, pengumpulan data, dan akhirnya presentasi hasil didepan kelas.

d) Guru meminta beberapa siswa untuk menyanyikan lagu yang sudah dipelajari di depan kelas dan mengucapkan vocabularies yang terdapat dalam lagu itu dan menterjemahkannsya ke dalam bahasa Indonesia. Siswa yang lain mendengarkan dan memperhatikan kata - kata yang diucapkan apakah sudah benar sebagai koreksi bagi siswa berikutnya. Demikian seterusnya, mereka bisa saling bergantian . Yang harus diingat bahwa para siswa harus senantiasa menggunakan bahasa Inggris sebagai alat komunikasi mereka.

1. Tahap Observasi Tindakan

Tahap observasi ini dilaksanakan pada saat berlangsungnya kegiatan pembelajaran. Hal ini untuk mengetahui tentang pemahaman siswa pada proses pembelajaran peningkatan vocabularies siswa melalui pengguanaan lagu - lagu dalam bahasa Inggris dengan memilih lagu - lagu yang disukai siswa dan terutama berkaitan dengan materi yang diajarkan sebagai sumber inspirasi belajar.

Hal ini sebenarnya tidak begitu asing bagi mereka, sehingga mudah difahami dan diterapkan bagi mereka. Adapun cara observasi tindakan dilakukan dengan:

1. Wawancara dengan siswa yang diambil secara random (acak) untuk mengetahui apakah siswa memiliki antusiasme pada proses pembelajaran vocabularies dengan penggunaan lagu - lagu dalam bahasa Inggris.

2. Penilaian langsung pada saat siswa menyanyikan dan melafalkan kata - kata yang terdapat lagu tersebut.

Setelah berakhirnya tahap observasi ini untuk mengetahui sejauh mana siswa menangkap materi pembelajaran kemudian diadakan test akhir kompetensi dasar atau post-test berupa tes sederhana secara lisan.

Dari test yang dilaksanakan, diperoleh hasil sebagai berikut:

a) Rata - rata nilai seluruh siswa adalah $=80$

b) Rata - rata nilai hasil observasi siswa yang antusias dan aktif dalam pembelajaran adalah $80 \%$ dan yang kurang aktif (tidak antusias) adalah $20 \%$.

c) Rata-rata siswa yang sudah mencapai nilai kreteria ketuntasan minimal (KKM), adalah $92 \%$.

d) Dari hasil ulangan setelah siklus I, hasilnya dibandingkan dengan hasil test berbicara sebelumnya, mengalami peningkatan/kenaikan dari rata - rata 30 menjadi 80 .

1. Tahap Refleksi 
Pada tahap pelaksanaan refleksi ini, setelah dilakukan pembelajaran melalui lagu-lagu dalam bahasa Inggris dengan menggunakan lagu - lagu yang disukai dan berkaitan dengan materi pelajaran sebagai sumber inspirasi belajar dan kemudian diakhiri dengan evaluasi (post-test), maka diperolehlah nilai sebagai perwujudan dari hasil pembelajaran yang telah dilaksanakan yakni test lisan. Dari nilai yang diperoleh kemudian dilakukan analisis sebagai berikut.

1) Menghitung rata - rata nilai dari seluruh siswa pada kelas tersebut.

2) Menghitung rata - rata dari hasil observasi siswa yang antusias dan aktif dalam pembelajaran dan siswa yang kurang aktif (tidak antusias).

3) Menghitung rata - rata siswa yang sudah mencapai nilai kreteria ketuntasan minimal (KKM).

Beberapa refleksi dari hasil observasi dan evaluasi dari siklus pertama ini dapat dipaparkan sebagai berikut:

a) Suasana kelas jadi ramai, maka pada siklus berikutnya peneliti harus mampu mengarahkan agar keramaianya bisa lebih bermakna, sebab keramaian pasti muncul sebagai akibat dari menyanyikan lagu - lagu bahasa Inggris yang asing bagi mereka.

b) Ada beberapa siswa yang masih pasif, maka peneliti pada siklus berikutnya adalah memberi stimulan agar lebih aktif partisipatif.

c) Ada beberapa siswa yang pada awal kegiatan nampak antusias, tetapi pada akhir kegiatan terlihat jenuh maka peneliti pada siklus berikutnya adalah memberi semangat agar tetap mampu menjaga keseriusanya dan agar tidak jenuh, siswa diajak menyanyi.

d) Dalam bernyanyi, bahasa Indonesia dan bahasa daerah setempat masih mendominasi dalam berkomunikasi satu sama lain maka peneliti pada siklus berikutnya adalah mengarahkan supaya lebih banyak menggunakan bahasa inggris dalam bernyanyi dan diingatkan agar tidak takut salah.

1. Siklus II

Sebagaimana yang dilakukan pada siklus sebelumnya, siklus ke II ini juga meliputi perencanaan, tindakan, observasi dan refleksi. Adapun pada tahap perencanaan peneliti merancang skenario pembelajaran dengan menggunakan lagu - lagu dalam bahasa Inggris dengan langkah-langkah sebagai berikut:

a) Guru menyampaikan tujuan dan memberikan motivasi tentang pentingnya belajar vocabularies.

b) Guru menjelaskan tentang cara-cara belajar vocabularies melalui lagu - lagu dalam bahasa Inggris dengan menggunakan lagu - lagu yang disukai dan yang sesuai dengan materi pelajaran sebagai sumber inspirasi belajar.

c) Guru memberi tugas individu dimana para siswa diminta untuk mencatat kosa kata (vocabulary) dalam bahasa inggris.

d) Guru mengintruksikan siswa untuk menyanyikan lagu tersebut.

1. Tahap Observasi Tindakan

Tahap observasi ini dilaksanakan pada saat berlangsungnya kegiatan pembelajaran. Hal ini untuk mengetahui tentang pemahaman siswa pada proses pembelajaran berbicara bahasa Inggris melalui lagu-lagu dalam bahasa inggris, dengan 
tujuan para siswa mampu mengembangkan kemampuan untuk menguasai kosa kata (vocabulary) dalam bahasa Inggris. Adapun cara observasi tindakan dilakukan dengan:

1) Wawancara dengan siswa yang diambil secara random (acak) untuk mengetahui apakah siswa memiliki antusiasme pada proses pembelajaran dalam bernyanyi dengan tujuan penguasaan kosa kata di dalam bahasa Inggris.

2) Penilaian langsung pada saat siswa berada di depan kelas, ketika mereka menyanyikan lagu-lagu dalam bahasa Inggris.

Setelah berakhirnya tahap observasi ini untuk mengetahui sejauh mana siswa menangkap materi pembelajaran kemudian diadakan test akhir kompetensi dasar atau post-test berupa tes sederhana secara lisan.

Dari test yang dilaksanakan, diperoleh hasil sebagai berikut:

a) Rata-rata nilai seluruh siswa adalah $=80$

b) Rata-rata nilai hasil observasi siswa yang antusias dan aktif dalam pembelajaran adalah $80 \%$ dan yang kurang aktif (tidak antusias) adalah $20 \%$.

c) Rata-rata siswa yang sudah mencapai nilai kreteria ketuntasan minimal (KKM), adalah $96 \%$.

d) Dari hasil ulangan setelah siklus I, dibandingkan dengan hasil test berbicara sebelumnya, mengalami peningkatan/kenaikan yang signifikan dari nilai rerata 30 menjadi 80

\section{Tahap Refleksi}

Pada tahap pelaksanaan refleksi ini, setelah dilakukan pembelajaran melalui lagu-lagu bahasa inggris dan kemudian diakhiri dengan evaluasi (post-test), maka diperolehlah nilai sebagai perwujudan dari hasil pembelajaran yang telah dilaksanakan yakni test lisan. Dari nilai yang diperoleh kemudian dilakukan analisis sebagai berikut.

1) Menghitung rata-rata nilai dari seluruh siswa pada kelas tersebut.

2) Menghitung rata-rata dari hasil observasi siswa yang antusias dan aktif dalam pembelajaran dan siswa yang kurang aktif (tidak antusias).

3) Menghitung rata-rata siswa yang sudah mencapai nilai kreteria ketuntasan minimal (KKM).

Adapun gambaran beberapa refleksi dari hasil observasi dan evaluasi pada siklus II ini dapat dipaparkan sebagai berikut:

\begin{tabular}{|l|l|l|l|}
\hline No. & Masalah Siklus I & \multicolumn{1}{|c|}{$\begin{array}{c}\text { Solusi Pada } \\
\text { Siklus II }\end{array}$} & \multicolumn{1}{|c|}{ Hasil } \\
\hline 1 & $\begin{array}{l}\text { 1. Suasana kelas } \\
\text { jadi ramai }\end{array}$ & $\begin{array}{l}\text { Diarahkan } \\
\text { Agar keramaianya } \\
\text { terkendali dan } \\
\text { bermakna. }\end{array}$ & $\begin{array}{l}\text { Siswa terarah, } \\
\text { terkendali, dan } \\
\text { lebih bermakna. }\end{array}$ \\
\hline 2 & $\begin{array}{l}\text { Ada beberapa } \\
\text { siswa yang masih } \\
\text { pasif. }\end{array}$ & $\begin{array}{l}\text { Diberi stimulan } \\
\text { agar lebih aktif } \\
\text { partisitif. }\end{array}$ & $\begin{array}{l}\text { Siswa sudah mulai } \\
\text { Aktif dan } \\
\text { partisipatif dalam } \\
\text { menyanyikan } \\
\text { lagu. }\end{array}$ \\
\hline 3 & $\begin{array}{l}\text { Ada beberapa } \\
\text { siswa yang pada } \\
\text { awal kegiatan }\end{array}$ & $\begin{array}{l}\text { Diberi semangat } \\
\text { agar tetap mampu } \\
\text { menjaga }\end{array}$ & $\begin{array}{l}\text { Semangat dapat } \\
\text { terjaga ,tidak } \\
\text { merasa jenuh dan }\end{array}$ \\
\hline
\end{tabular}




\begin{tabular}{|c|c|c|c|}
\hline & $\begin{array}{l}\text { nampak antusias, } \\
\text { tetapi pada akhir } \\
\text { kegiatan terlihat } \\
\text { jenuh. }\end{array}$ & \begin{tabular}{l}
\multicolumn{2}{c}{ keseriusanya dan } \\
agar tidak jenuh \\
siswa \\
menyanyi.
\end{tabular} & $\begin{array}{l}\text { nampak } \\
\text { bersemangat lagi } \\
\text { setelah sejenak } \\
\text { diajak menyanyi. }\end{array}$ \\
\hline 4 & $\begin{array}{l}\text { Dalam diskusi, } \\
\text { bahasa Indonesia } \\
\text { masih } \\
\text { mendominasi } \\
\text { dalam } \\
\text { berkomunikasi } \\
\text { satu sama lain. }\end{array}$ & $\begin{array}{l}\text { Diarahkan supaya } \\
\text { lebih banyak } \\
\text { menggunakan } \\
\text { bahasa Inggris } \\
\text { dalam diskusi dan } \\
\text { diingatkan agar } \\
\text { tidak takut salah. }\end{array}$ & $\begin{array}{l}\text { Menjadi lebih } \\
\text { banyak } \\
\text { menggunakan } \\
\text { Inggris walaupun } \\
\text { dengan bahasa } \\
\text { komunikasi yang } \\
\text { kurang teratur } \\
\text { tetapi sudah } \\
\text { lebih baik } \\
\text { dari sebelumnya. }\end{array}$ \\
\hline
\end{tabular}

\section{A. Hasil Penelitian}

Dari hasil pelaksanaan tindakan selama dua kali siklus dapat dibuat secara ringkas dalam bentuk table sebagai berikut:

\begin{tabular}{|l|l|l|l|l|}
\hline No. & Indikator & Pra-Siklus & \multicolumn{2}{|c|}{ Presentasi/Hasil } \\
\cline { 3 - 5 } & & & Siklus I & Siklus II \\
\hline 1 & $\begin{array}{l}\text { Rata - rata nilai } \\
\text { seluruh siswa }\end{array}$ & 60 & 60 & 70 \\
& $\begin{array}{l}\text { Rata }- \text { rata } \\
\text { jumlah dari } \\
\text { hasil observasi } \\
\text { siswa yang } \\
\text { antusias dan } \\
\text { aktif dalam } \\
\text { pembelajaran }\end{array}$ & $\begin{array}{l}\text { Tidak } \\
\text { terdeteksi }\end{array}$ & 70 & 75 \\
\hline 3 & $\begin{array}{l}\text { Rata - rata } \\
\text { jumlah siswa } \\
\text { yang sudah } \\
\text { mencapai nilai } \\
\text { kreteria } \\
\text { ketuntasan } \\
\text { minimal (KKM) }\end{array}$ & & & \\
terdeteksi & 70 & \\
& & & \\
\hline
\end{tabular}

Secara umum dapat dinyatakan bahwa dilihat dari 3 (tiga) indikator dan hasil tindakan siklus I dan II dari pra-siklus menuju siklus pertama menunjukan kecenderungan positif, kemudian setelah siklus pertama dilakukan perbaikan menunjukan peningkatan yang signifikan pada semua indikator.

Dari paparan di atas maka penggunaan lagu - lagu bahasa Inggris memberikan suatu rangsangan pada siswa (peserta didik) untuk lebih aktif dan kreatif dalam mengikuti pembelajaran berbicara bahasa Inggris, selain itu dari data diatas menunjukan bahwa indikator-indikator penelitian telah mulai nampak keberhasilan pada siklus I 
sampai siklus II, akhirnya bisa terlihat semua indikator penelitian telah mencapai target bahkan melampaui target.

1. Pembahasan

Ditinjau dari deskripsi per siklus dan juga deskripsi antar siklus menunjukan bahwa hasil prestasi belajar berbicara bahasa Inggris kelas 8 mengalami peningkatan. Setelah siklus II diselesaikan, hasil prestasi jauh lebih baik dibandingkan dengan hasil prestasi sebelum dilakukan (diterapkan pembelajaran vocabularies melalui lagu-lagu dalam bahasa Inggris).

Setelah melalui proses adaptasi pada siklus I baru kemudian menampakan hasil yang cukup signifikan peningkatannya. Dalam hal ini terlihat siswa lebih termotivasi dan semangat dalam pembelajaran bahasa inggris. Presentasi keaktifan yang tinggi serta rata - rata nilai yang telah mencapi 80 , nilai rata-rata tersebut telah melampaui KKM, menunjukkan bahwa penggunaan lagu-lagu dalam bahasa Inggris tersebut dapat diterima dan dipahami oleh siswa.

Penggunaan lagu-lagu bahasa Inggris dalam pembelajaran sebagai sumber inspirasi belajar sangat efektif untuk menumbuhkan semangat belajar, kreatifitas serta kebersamaan pada siswa. 


\section{KESIMPULAN}

Melalui pendekatan penggunaan lagu-lagu bahasa Inggris dalam pembelajaran sebagai sumber inspirasi belajar telah memberikan kontribusi dalam meraih keberhasilan pembelajaran vocabularies. Setelah peneliti mengevaluasi dan merefleksi dari hasil setiap siklus, disimpulkan bahwa siswa mengalami peningkatan vocabularies dalam bahasa inggris. Peningkatan kemampuan vocabularies dibuktikan melalui keberhasilan siswa dalam menempuh tes tertulis.Hasil dari pemberian tindakan untuk tiap-tiap putaran atau siklus menunjukan bahwa kemampuan berbicara bahasa Inggris siswa meningkat dari nilai rata - rata 30 sebelum diberi tindakan menjadi 80 setelah akhir pemberian tindakan.

Peneliti menyimpulkan bahwa melalui pendekatan penggunaan lagu-lagu bahasa Inggris sebagai sumber inspirasi belajar mampu meningkatkan vocabularies siswa. 


\section{DAFTAR PUSTAKA}

Alamsetiadi 08's Weblog. Upaya Peningkatan Vocabulary Siswa dengan Media Wordwall.

Bisri mustofa, Ali hasan. 2010. Manajemen Pendidikan. Jakarta: Penerbit Kreasi SatuDelapan:

Bisri Mustofa Djaelani. 2010. Etika Dan Profesi Guru. Jakarta: Penerbit Multi Kreasi SatuDelapan

Harun Rasyid, Mansur. 2007. Penilaian Hasil Belajar. Bandung: Penerbit CV Wacana Prima

H. Mohammad Asrori. 2007. Penelitian Tindakan Kelas. Bandung: CV. Wacana Prima

Istiyah, asih Marwati.2010. Media Pembelajaran Siswa Aktif. Jakarta: Penerbit Multi Kreasi SatuDelapan

Rudi Susilana, Cepi Riyana. 2007. Media Pembelajaran. Bandung: Penerbit CV Wahana Prima

Sukidin, et.al.2008. Manajemen Penelitian Tindakan Kelas. Jakarta: Penerbit Insan Cendekia. 